
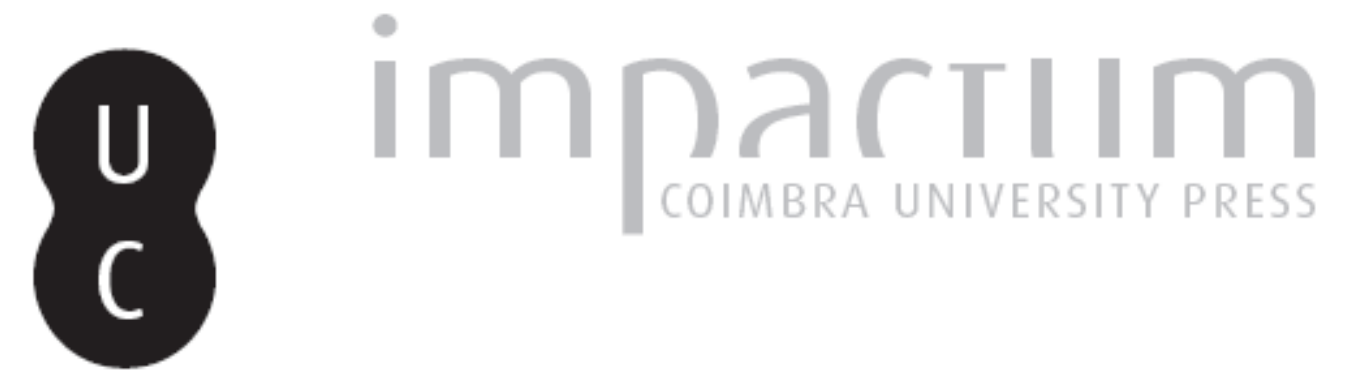

\title{
No rasto de problemas actuais da História
}

\section{Autor(es): Dwarkasing, Ana Leonor Pereira}

Publicado por: Imprensa da Universidade de Coimbra

URL persistente:

http://hdl.handle.net/10316.2/42924

DOI:

https://doi.org/10.14195/2183-8925_11_17

Accessed : $\quad$ 26-Apr-2023 13:07:55

A navegação consulta e descarregamento dos títulos inseridos nas Bibliotecas Digitais UC Digitalis, UC Pombalina e UC Impactum, pressupõem a aceitação plena e sem reservas dos Termos e Condições de Uso destas Bibliotecas Digitais, disponíveis em https://digitalis.uc.pt/pt-pt/termos.

Conforme exposto nos referidos Termos e Condições de Uso, o descarregamento de títulos de acesso restrito requer uma licença válida de autorização devendo o utilizador aceder ao(s) documento(s) a partir de um endereço de IP da instituição detentora da supramencionada licença.

Ao utilizador é apenas permitido o descarregamento para uso pessoal, pelo que o emprego do(s) título(s) descarregado(s) para outro fim, designadamente comercial, carece de autorização do respetivo autor ou editor da obra.

Na medida em que todas as obras da UC Digitalis se encontram protegidas pelo Código do Direito de Autor e Direitos Conexos e demais legislação aplicável, toda a cópia, parcial ou total, deste documento, nos casos em que é legalmente admitida, deverá conter ou fazer-se acompanhar por este aviso.

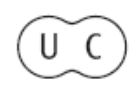


REVISTA DE HISTÓRIA DAS IDEIAS 11

\section{CULTURA POLÍTICA MENTALIDADES}

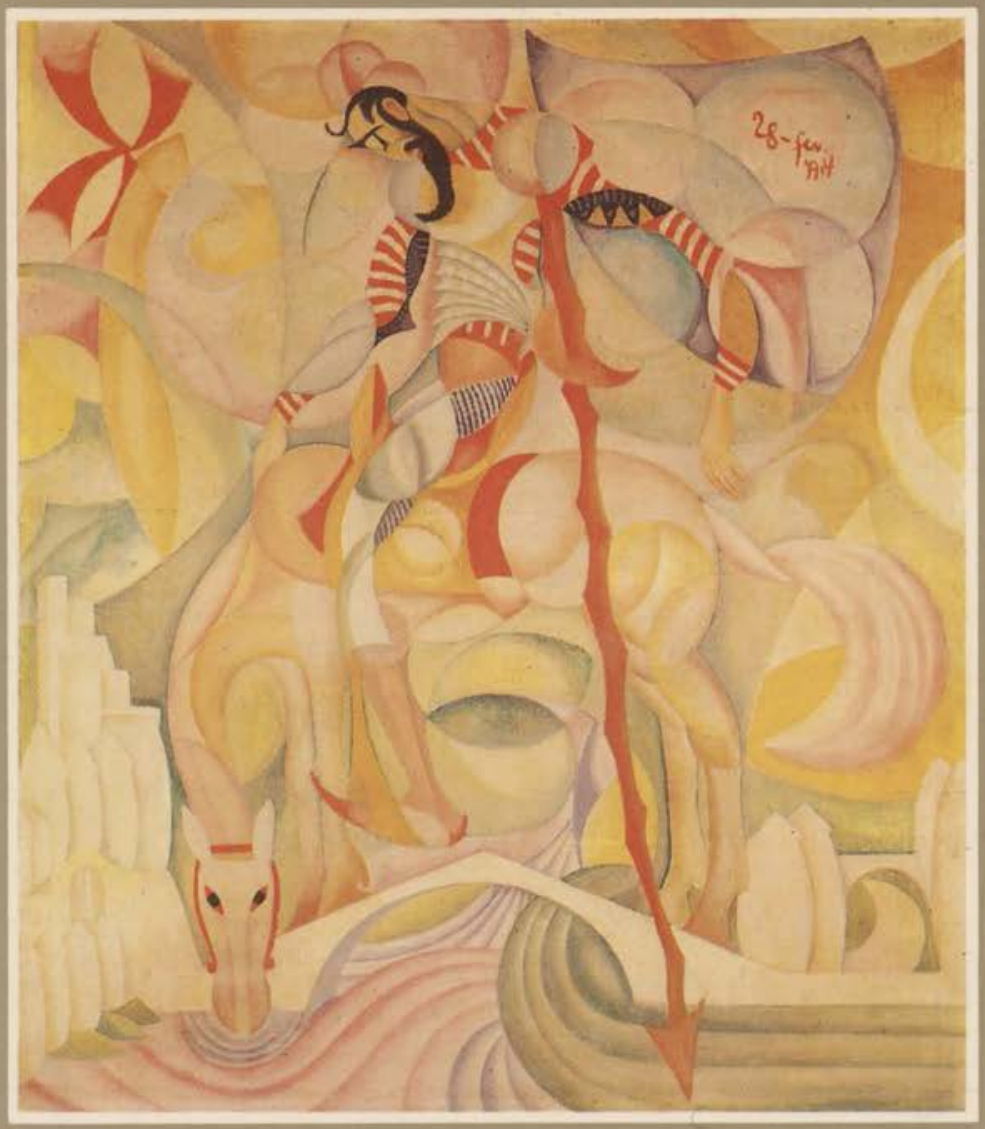

INSTITUTO DE HISTORIA E TEORIA DAS IDEIAS FACULDADE DE LETRAS 


\section{NO RASTO DE PROBLEMAS ACTUAIS DA HISTÓRIA}

Introdução: exemplos de alguns focos problemáticos enquanto elementos justificativos da necessidade de discursos do método nas ciências historiográficas.

1-Metamorfoses do sistema e tensões na floresta historiográfica. Dados para uma resposta provisória às perguntas: a sistematização formalizada do saber histórico funda a tentação cientista de reduzir ao unidimensional a polivalência sincrónica e diacrónica da historicidade? A historiometria do sócio-cultural suscita o retorno do «paradigma perdido» (Edgar Morin)?

II - Para o problema da relação da história com a sua actualidade. Exposição sumária da resposta da primeira historiografia positivista ao seu tempo. A sua estratégia face às mudanças epistémicas de oitocentos, em particular face d̀ ofensiva do sociologismo. Necessidade de se rever a lição positivista para considerar as actuais posições da história no quadro geral do saber.

Conclusão: politicas da historiografia, um problema a colocar «na fronteira da prática historiográfica $e$ da reflexão filosófica» (Roger Chartier).

* Faculdade de Letras da Universidade de Coimbra.

** Agradeço ao Prof. Doutor Luís Reis Torgal e ao Prof. Doutor Amadeu Carvalho Homem as sugestões que, tão amavelmente, me deram, a partir da leitura da primeira versão deste artigo. 
"A ciência histórica conheceu, desde há meio século um avanço prodigioso: renovação, enriquecimento das técnicas e dos métodos, dos horizontes e dos domínios. Mas, mantendo com as sociedades globais relações mais intensas do que nunca, a história profissional e científica vive uma crise profunda. $\mathrm{O}$ saber da história é tanto mais confuso, quanto mais o seu poder aumenta».

Jacques Le Goff, «História» in Enciclopédia Einaudi. 1. Memória-História, Imprensa Nacional, 1984, p. 161 (sublinhado nosso).

"Nous sommes, comme on voit, dans l'enfer de la confusion, dans une de ces situations pourries où les choses sont pensées à demi, assez pour qu'on ne puisse être taxé de naïveté, pas assez pour qu'on ose tirer au clair les conventions arbitraires et les fausses conséquences qu'on en tires.

Paul Veyne, Comment on écrit l'histoire suivi de Foucault révolutionne l'historie, Paris. Seuil, 1978, p. 193 (sublinhado nosso).

«Des césures existent parfois brutales, même si toutes ne s'appellent point 'révolution' et il serait illusoire de les méconnaître».

Michel Vovelle in Vários, L'Evenement, Université de Provence, 1986, p. 332.

NOTA: Ao longo do artigo usamos o termo história no sentido de historiografia. 


\section{Introdução}

As declarações de Jacques Le Goff e de Paul Veyne colocadas em epígrafe mostram, sem rodeios, que a História tem vivido tempos particularmente complexos e críticos, tributários da "encruzilhada epistemológica" ( ${ }^{1}$ ) em que se encontra envolvida, para usar a expressão sugestiva de Luís Reis Torgal.

$\mathrm{Na}$ verdade, é difícil encontrar "as coisas simples» na floresta historiográfica actual e não se espere que elas sejam aqui desveladas porque, como avisou Descartes, a clareza e a distinção alcançam-se mediante um perguntar metódico, firme e seguro, de que não dispomos. Assim, à partida, não está realizada esta condição de produção de certezas. Recordemos a prosa cartesiana que tem quase 352 anos e, no dizer de Alexandre Koyré $\left({ }^{2}\right)$, nunca foi tão actual como hoje: «Le bon sens est la chose au monde la mieux partagée....» $\left({ }^{3}\right)$; mas não nos iludamos porque, acrescenta o filósofo, só por si, isto é, espontaneamente, a razão ou "bom senso» não é capaz de separar o verdadeiro do falso. Tomemos, então, consciência de que não podemos ultrapassar as impressões mais ou menos cegas no sentido de evidenciar o que se passa na historiografia, hoje, porque, repita-se, não vemos claro no que toca às regras do perguntar pela experiência historiográfica. Não obstante,

(1) Luís Reis Torgal, "A Revolução Francesa no ensino da História em Portugal», Revista de História das Ideias, n..$^{\circ}$, Coimbra, 1988 , p. 604 (sublinhado nosso).

(2) Alexandre Koyré, Considerações sobre Descartes, Lisboa, Editorial Presença, 2.a ed., 1981, p. 93.

( ${ }^{3}$ Descartes, Discours de la Méthode suivi des Méditations. Présentation de Jean-Paul Sartre, Marabout Université. 1974, p. 29. 
queremos caminhar, mesmo ignorando como percorrer a tloresta, que preceitos seguir para surpreender as verdades que ela produz e consome, os valores que constrói e desconstrói, as crenças que cultiva e as que recusa.

Comecemos por atirmar algo que é banal e óbvio o que não quer dizer que seja "claro e distinto»: a escrita da história segrega problemas imprecisos e fluidos; matérias que deslizam para os seus rizomas, aí permanecendo inquietas e actuantes dentro e fora da obra, gerando tons, nuanças, fugas de sentido que tanto podem fortalecer como enfraquecer os resultados científicos da prática historiográfica. Seria bastante útil que o historiador pudesse dispor de uma psicanálise do conhecimento histórico (inspirada em Gaston Bachelard $\left({ }^{4}\right)$ e seus discípulos) na medida em que esta arte científica poderia clarificar muitos daqueles problemas. Julgamos que este juízo é partilhado por todos os historiadores que, afinal, independentemente do género de história que constroem, perseguem o verdadeiro, seja qual for o sentido que atribuem a este termo.

A procura da verdade não implica necessariamente uma queda no princípio hegeliano da unidade e identidade do pensamento e do ser, mas nem por isso está isenta de obstáculos, de figuras problemáticas que emergem no decurso da prática historiográfica. Mesmo não sofrendo daquela «doença metafísica" a objectivação histórica tem uma complexidade sui generis. E corrente distingui-la desde logo das ciências ditas duras, basicamente porque é impossível converter a história num laboratório, repetir experiências, manipular o tempo do acontecer, estabelecer leis e prever. Em termos sensitivistas ouçamos o que o célebre "ideólogo" $\left(^{5}\right)$ Volney ensinava: «L'histoire, si l'on veut la considérer comme une science,

(4) Veja-se Gaston Bachelard, A Epistemologia, Lisboa, Ed. 70, 1984, pp. 165-190.

(5) Volney pertence à geração de Destutt de Tracy, Daunou, Cabanis e outros que Napoleâo baptizou depreciativamente de «ideólogos». Situada entre o movimento iluminista e o romantismo, esta geração foi "victime d'une sorte de complot, parce que sa liberté d'esprit en matière politique et religieuse n'a cessé d'inquiéter les pouvoirs sucessifs qui ont dominé la France: Napoléon jugeait les Ideólogues de dangereux indépendants et le cléricalisme officiel de 1815 à 1877 les condamne comme subversifs de toute moral» (Jean Gaulmier in C. F. Volney, La Loi Naturelle. Leçons D'Histoire, presenté par Jean Gaulmier, Paris, Éditions Garnier Frères, 1980. p. 9). O pensamento dos ideólogos continua a ser desvalorizado. Por exemplo, o recente Dictionnaire des Sciences Historiques sous la direction de André Burguière, Paris, P.U.F., 1986, omite-o. Também, sintomaticamente, nenhum artigo é dedicado ao termo ideologia. 
diffère absolument des sciences physiques et mathématiques. Dans les sciences physiques, les faits subsistent; ils sont vivants et l'on peut les représenter au spectateur et au témoin. Dans l'histoire, les faits n'existent plus; ils sont morts, et l'on ne peut les ressusciter...." $\left({ }^{6}\right)$. Apesar do empirismo destes enunciados, eles estabelecem uma diferença pertinente que nos parece ter sido sempre reconhecida pela historiografia mesmo por aquela que postula o facto positivo. Diga-se, pois, que a história tem em consideração os limites que lhe são impostos pela natureza do tempo, embora nem sempre tenha admitido que o facto histórico é construído, como também o é, por outros processos. o facto físico.

Cabe aqui sublinhar que esta questão propedêutica aguarda um tratamento sistemático, rigoroso e alargado pois a imagem da física atormenta a história desde o tempo de Volney, pelo menos, e hoje, como veremos adiante, é o seu referente de comparação privilegiado quer se trate de distância quer de proximidade. Apesar de ser possível colocar o problema da história enquanto ciência de modos diversos, é difícil evitar a presença, ainda que inconsciente, da ciência-modelo e os efeitos que ela desencadeia no equacionamento das várias faces do tema.

Por outro lado, queremos dizer que esta complexa matéria (que só por si bem merecia a dedicação de um tratadista experiente e idóneo) nunca inibiu o historiador de procurar uma inteligibilidade do histórico em consonância com sentidos de produção de verdade diversos desde a utilidade social, como era o caso de Volney $\left({ }^{7}\right)$, até à erudição contemplativa. Ao contrário do que se poderia ser levado a pensar, isto significa que além de problemas comuns a toda a actividade historiográfica, problemas globais e regionais tais como métodos, terminologias, modelos hermenêuticos, há ainda problemas particulares que denotam a singularidade de cada obra, fazem parte dela e apelam de modo especial para o seu autor.

(') C. F. Volney, ob. cit., p. 87. No mesmo sentido escreve Georges Lefebvre: «L'histoire diffère profondément des sciences expérimentales parce qu'elle ne peut observer directement les faits....", La naissance de l'historiographie moderne, Paris, Flammarion, 1971, p. 33.

(7) Cf. Georges Gusdorf, La Conscience Révolutionnaire. Les Idéologues, Paris, Payot, 1978 (tomo VIII de Les Sciences Humaines et la Pensée Occidentale), Section III. Domaines. C. Histoire. "Les leçons d'histoire de Volney», p. 506 e ss. 
Muitas razões de superfície poderiam ser invocadas para inteligir a tolerância, a boa-fé e o desprendimento do historiador relativamente aos problemas activos que se auto-governam na obra, contra a vontade de máxima verdade possível do autor. Não nos vamos entreter com essas razões porque nada adiantaríamos.

Sejamos breves e directos: a história, hoje, precisa de discursos do método, isto é, de exposições de caminhos e, embora seja uma tarefa pouco aliciante e particularmente delicada, temos entre nós (pensamos em Coimbra) historiadores idóneos que poderiam realizá-la, dando assim um contributo de grande valia para desenvolver a auto-consciência historiográfica, afirmar o carácter inacabado e aberto dos estudos históricos, evidenciar as suas tensões internas, a sua disciplina ou o modo de a estabelecer, etc.

Já na sua obra A História como Ciência, José Amado Mendes chama a atenção dos historiadores para a necessidade de não se descuidar ou remeter para segundo plano as questões teóricas pois "sem teoria não há história» $\left({ }^{8}\right)$. Nesta base, gostaríamos de acrescentar que além dos problemas já entreabertos o discurso do método por vir $\left(^{{ }^{\circ}}\right)$ não deve esquecer a questão da unidade da história. Esta implica o equacionamento exaustivo do problema do singular e do universal, "a contradição mais flagrante da história» como escreve Jacques Le Goff $\left({ }^{10}\right)$; magno problema do qual depende o estatuto literário e científico da história por um lado e o modo de ser da sua unidade, por outro lado. E comum entender-se a compreensão histórica do singular como uma arte de contar e de estabelecer intrigas e o tratamento do universal, não na sua acepção metafísica, mas enquanto tendência regular de uma determinada unidade geo-histórica como a vertente científica da história. Quando se observa de modo empírico e superficial a produção historiográfica contemporânea salta à vista a área da história demográfica, económica e social, enquanto história científica que já conquistou um certo poder de previsão: "probabilística; de míope (isto é, feita de curta distância); de puras tendências gerais)" $\left({ }^{11}\right)$ - mas, em todo o caso, previsão. 0 mesmo não se

(8) José M. Amado Mendes, A História como Ciência. Fontes, Metodologia e Teorização, Coimbra Editora, 1987, pp. 209-210.

(9) Pensamos na obra de Maurice Blanchot, Le livre à venir, Paris. Gallimard, 1959.

(10) Jacques Le Goff, "História», in Enciclopédia Einaudi 1: Memória-História, Lisboa, Imprensa Nacional, 1984, p. 169.

(1i) José Amado Mendes, ob. cit., p. 209. 
pode dizer da história político-cultural. A substância desta história não reside tanto nos cálculos estatísticos e nas disposições cartográficas mas sobretudo na prosa que a tece. Em termos relativos talvez não haja antagonismo entre prosa-singular e ciência-universal mas parece-nos ser aceite por todos os historiadores que "o grande problema é o da história global, geral, a tendência secular de uma história que não seja só universal e sintética...., mas integral ou perfeita, como dizia La Popelinière, ou global, total, como exigiam os Annales de Lucien Febvre ou Marc Bloch» ( $\left.{ }^{12}\right)$. As dificuldades surgem logo ao nível da enunciação do problema porque assim colocado torna-se evidente a necessidade de distinguir e precisar certas categorias que mesmo nos textos dos grandes historiadores são tomadas como equivalentes. Aqui, é o caso de global, geral, universal e total. Eis, para nós, uma indefinição que se impõe ultrapassar e talvez, em parte, ela resulte da presença silenciosa da filosofia da história oitocentista, na forma de conceber a unidade da história. Mas, se é legítimo simplificar o enunciado do autor, diremos que o grande problema é o da história no singular, a construção da sua unidade pela articulação das diferentes histórias.

É fácil dizê-lo. Mas, como articular os vários planos, como estabelecer conexões estratégicas, se relacionar não é justapor nem encontrar coincidências cronológicas em séries que têm ritmos, níveis, fracturas, permanências, em suma, temporalidades diferentes? Talvez a história seja impossível e por isso não surpreende que Jacques Le Goff escreva: "há quem pense que o tempo da história esmigalhada chegou» $\left({ }^{13}\right)$.

Com efeito, ao que supomos, o relacionamento das séries tem de fazer-se tanto no plano horizontal como no plano vertical e isso implicará desde logo o exame da compreensão-explicação de tipo estruturalista que se tornou familiar entre os historiadores, mas que hoje já não responde às necessidades epistémico-hermenêuticas da história. Vejamos o exemplo dado por Lucien Goldmann: "Se estudar os Pensamentos de Pascal como estrutura significativa interna, tento compreendê-los; mas se em seguida os inserir como uma estrutura parcial numa estrutura mais vasta que é a do movimento jansenista, compreendo o jansenismo, e explico pelo jansenismo os Pensamentos de Pascal. E se inserir o movimento jansenista na estrutura global da nobreza de toga, compreendo a história da nobreza de toga e através dela explico a génese

(12) Jacques Le Goff, «art. cit.», p. 242.

(13) Idem, ibidem. 
do jansenismo. Se, em seguida, fizer a mesma operação com a nobreza de toga na França do séc. XVII, situo-me a um nível de explicação para essa nobreza de toga e a um nível de compreensão para a estrutura global» $\left({ }^{14}\right)$. Estamos perante vários problemas mas o fundamental, para nós, é o de saber como ultrapassar esta causalidade explicativa que unifica a hierarquização $\left({ }^{15}\right.$ ) rígida dos planos.

Queremos, no entanto, deixar bem claro que o questionamento deste modelo não deve pôr em causa a "revolução coperniciana" que o séc. XIX imprimiu na historiografia (o método positivo e o materialismo histórico); ambos, inegavelmente, continuam a conduzir os estudos históricos. José Mattoso di-lo claramente: "Os grandes progressos da historiografia contemporânea resultam, a meu ver, dos caminhos novos abertos por duas grandes correntes: o positivismo e o marxismo" $\left({ }^{16}\right)$.

$\mathrm{Na}$ verdade, pondo de lado as pretensões da metafísica $\left({ }^{17}\right)$, como abrir o caminho para uma nova unidade da história sem uma reavaliação prévia do modelo marxista-estruturalista de compreensão global? É óbvio que a unidade da história exige muito mais do que isto. Como embraiar as determinações das diversas temporalidades horizontais das séries? Como coordenar diacronia e sincronia? Recorrendo à teoria dos sistemas? Ou então à teoria dos jogos? Possivelmente. $O$ que se sabe com toda a certeza é que semelhante construção exige um trabalho de equipa planificado e coordenado com rigor. Em duas palavras: parece-nos evidente que o problema da unidade da história merece e exige ser analisado em todos os seus níveis. Apenas quisemos passar por ele (não o equacionámos) para registar que importa tratá-lo mesmo que os cépticos tenham razão ao afirmar com Paul Veyne: "comme totalité, l'Histoire nous échappe et, comme entrecroisement de séries. elle est un chaos semblable à l'agitation d'une grande ville vue d'avion" ${ }^{(18)}$. A metáfora é

(14) Lucien Goldmann. A Criacão Cultural na Sociedade Moderna, Lisboa Ed'torial Presença, 2." ed., 1976, p. 23.

(15) Veja-se a crítica veyniana ao modelo marxista, enquanto tentativa de geologizacão fisicalista da história; Paul Vevne, Comment on écrit l'histoire suivi de Foucault révolutionne l'histoire, Paris, Seuil, 1978, p. 181.

(16) José Mattoso, A Escrita da História. Teoria e métodos, Lisboa, Editorial Estampa, 1988, p. 109.

(17) Veja-se Max Horkheimer. Les Débuts de la Philosophie bourgeoise de l'histoire suivi de Hegel et le problème de la métaphysique. Traduit de l'allemand par Denis Authier, Paris, Payot, 1974.

(18) Paul Veyne, ob. cit., p. 30. 
bela, o que reforça a indeterminação dos seus sentidos. A revelia do seu autor, ela pode estimular a pesquisa da ordem no caos e criar no historiador a vontade de romper com o seu itinerário solipsista. Todos sentimos quanto é urgente construir mapas geo-políticos, sociais, culturais, económicos, demográficos e outros; como seria precioso avaliar, seleccionar e instituir leques de mediadores conceptuais, lógicos, metodológicos e cartográficos. Com efeito, se dispusesse de uma semelhante caixa de ferramentas, o historiador não se sentiria desorientado perante a face caótica, labiríntica e incontrolável da história, como certamente acontece, por vezes, a muitos de nós.

Voltemos, por alguns instantes ao singular. Que destino lhe reserva a história político-cultural? Tomá-lo como símbolo? Desvanecê-lo no serial? O que fazer do indivíduo? É a morte do homem que se aproxima como anunciou Michel Foucault $\left({ }^{19}\right)$ no final de Les mots et les choses? Talvez ainda seja cedo, pelo menos no que toca à historiografia nacional.

Este problema, para nós, é ainda mais embaraçoso. Não é verdade que cada semente, cada flor, cada rosto ou movimento tem direito a um nome, a uma identidade? Sim. Será isto um preconceito jurídico? Talvez. Mas não deixa de ser o pulsar da natureza das coisas que a linguagem poética tem o dom de traduzir excelentemente. Nunca é demais repetir que todo o ser vivo é uma unidade única. Cada indivíduo é original e inédito: "....le chien qui est écrasé en ce jour est un autre que celui qui a été écrasé la veille...., aujourd'hui n'est pas la veille» $\left({ }^{20}\right)$. Cada singular é uno e único. Esta é a verdade da floresta; é também, com espantosa intensidade a certeza da experiência histórica. Não estamos a confundir história vivida e ciência histórica, nem a defender algum pós-modernismo historiográfico mas a querer dizer que o singular dá problemas à história sobretudo à história político-cultural. Neste caso, não é possível ser indiferente ao único e dar-lhe atenção não significa, para utilizar a expressão pitoresca criada por António Hespanha, cometer qualquer "pecado epistemológico original» $\left({ }^{21}\right)$. Mesmo que assim fosse, não seria caso para lamentar pois o pecado original é fonte

(19) Michel Foucault, Les mots et les choses. Une Archéologie des sciences humaines, Paris, Gallimard, 1966.

(20) Paul Veyne, ob. cit., p. 18.

(21) António Manuel Hespanha, «História e Sistema: Interrogações à Historiografia Pós-Moderna», Ler História, Lisboa, n. 9, 1986, p. 69. 
de conhecimento. Por outro lado, não há historiadores tão românticos que se dediquem ao singular. em si, isto é, ao acontecimento individual por si mesmo, fazendo tábua rasa de uma série de linhas que se cruzam nele, das intrigas com os seus diferentes ritmos temporais que o objectivam e em função dos quais ele emite determinados sinais. Apesar disto, o singular é um "bico-de-obra» que, obviamente, tambóm aguarda um verdadeiro tratamento.

Detenhamo-nos um pouco no precioso e oportuno artigo de António M. Hespanha. O autor, entre outros motivos pelos quais a história não tem ainda um ritmo de crescimento científico adequado às ofertas metodológica e tecnológica actuais, apresenta "o de os historiadores se obstinarem na ideia de que cada facto histórico deve ser apreendido e tratado globalmente, em toda a sua complexidade carregado de todas as suas determinações histórico-concretas» $\left({ }^{22}\right)$. Assim, na perspectiva do autor, a fixação nas singularidades constitui um obstáculo ao desenvolvimento da história mesmo no caso de uma inteligibilidade de tipo estruturalista, como no exemplo de Lucien Goldmann atrás referido, se a nossa interpretação é justa. Ora, no quadro da objectivação do singular, deve referir-se em especial a história biográfica. Será também a biografia uma barreira ao avanço da ciência histórica? Ou não será antes um dos efeitos do desenvolvimento historiográfico que se operou desde a década de 50 , na medida em que já não se trata de heroificar o indivíduo mas de o objectivar, desmitificar, e portanto, num certo sentido de o desindividualizar? De qualquer modo, julgamos que o interesse actual pela crónica singular é um fenómeno complexo e irredutível à leitura que o aponta como sendo o salto mortal da historiografia contemporânea. Todavia, o perigo da antropologização do saber histórico existe. Mas será este o grande motivo que inspira a censura do individual?

\section{Metamorfoses do sistema e tensões na floresta historiográfica}

As considerações de A. M. Hespanha relativas à história pós-moderna são fundamentais para aprofundar a auto-consciência historiográfica.

Com efeito, entre outras características da escrita da história actual merece particular registo «o cepticismo quanto

(22) Idem, ibidem, р. 73. 
ao sistema» $\left({ }^{23}\right)$. Certo. Mas, é preciso clarificar o código epistemológico que pode tornar possível a compreensão da referida prática historiográfica actual nestes moldes. Não o podemos reduzir a um exame, ainda que útil, dos preconceitos e hábitos dos historiadores. António Hespanha indica: «(a) a preguiça intelectual»; "(b) o atomismo»; "(c) o oportunismo metodológico"; "(d) o nihilismo conceitual e construtivo»; "(e) o impressionismo» $\left.{ }^{24}\right)$. É claro que, só o narcisismo intelectual poderá negar a evidência daqueles comportamentos historiográficos, apontados como negativos. No entanto, é ilusório julgar possível extrair o sentido daquilo que se passa na história, hoje, a partir dum inventário de atitudes. Não foi esta a intenção do autor mas é mérito do seu texto abrir espaços problemáticos onde ao lado de umas, nascem outras questões. $\mathrm{O}$ nosso propósito é apenas o de tentar delinear uma ou outra.

Desde logo, parece-nos, impõe-se reconhecer que o historiador é uma figura das Humanidades. Talvez porque o seu espírito seja acentuadamente lúdico, ele sabe, não apenas teoricamente mas ainda por intuição e experiência que. onde o espírito de sistema penetra, um certo estilo de jogo torna-se impossível. Mas ele também sabe que a aventura historiográfica não perde o seu encanto se a floresta se tornar geométrica e disciplinada. Nenhum historiador negará que o desenvolvimento dos estudos históricos depende em grande parte do recurso à informática e simultaneamente de uma planificação e distribuição coordenada das matérias por equipas $\left({ }^{25}\right)$ autênticas. Por outro lado. olhando de uma certa maneira a floresta historiográfica retem-se a agradável impressão de que a obra dos historiadores é uma presença do Belo, do sentido criador, estético e lúdico do homem e da mulher. Obra tão expressiva que quase nos leva a cair na ilusão de que toda a história é história pela história, como a arte, em si mesma, é arte pela arte. Como foi possível que a escrita da história

(23) Idem, ibidem, p. 70. Para o autor, o «texto paradigmático de uma nova forma de escrever a (nossa) história - como, há alguns anos, o foram textos de Sérgio ou de Godinho - $\rightarrow$ (p. 65) é a Identificação de um País. Ensaio sobre as Origens de Portugal. 1096-1325. I Oposição. II Composição, Lisboa, 1985, de José Mattoso.

(24) Idem, ibidem, p. 74.

(25) Dizemos equipas pois não se vê como de outro modo é possível caminhar no sentido de uma compreensão (aberta e necessariamente inacabada) do todo. $\mathrm{E}$, tal como a inteligibilidade global de um determinado todo não é redutível a um somatório de partes, também uma equipa não é um conjunto atomístico de participantes. Eis uma outra ordem de problemas que o discurso do método deve contemplar. 
tivesse conservado um privilégio tão raro face à dominação progressiva do pensamento sub specie machinae $\left({ }^{28}\right)$, desde a modernidade galilaica e cartesiana, em quase todas as áreas do saber? Isto significa que a escrita da história é fiel à experiência da historicidade que, por natureza, é aberta, imprevisível e polissémica? Não o sabemos. Todavia, parece-nos que a pergunta não está deslocada relativamente ao horizonte problemático em formação na actualidade que Boaventura de Sousa Santos traçou na sua Oração de Sapiência $\left({ }^{27}\right)$ em 1985.

É verdade que a história é uma ciência especial como em 1966 ficou singularmente expresso em Les mots et les choses. Ela não tem lugar no triedro dos saberes, figura que traduz a disposição dos mesmos na episteme moderna. E porquê? Basicamente, porque, quando irrompe o núcleo constituinte da originalidade do campo epistémico moderno, a história já lá está. Só por convenção se pode dizer que nasceu nesta ou naquela hora. Embora tenha renascido algumas vezes, a história é "tão velha como a memória humana" $\left({ }^{28}\right)$. Sendo uma ciência diferente, a sua própria história é irredutível a qualquer modelo de temporalidade fisicalista. Com efeito, ela conservou até hoje um certo estilo alquímico como indirectamente nos diz António Hespanha; a história não se deixou disciplinar pela razão técnica-calculadora ou maquinal.

Porquê, então, permiti-lo agora que a crise $\left({ }^{29}\right)$ do modelo de racionalidade maquinal-estruturalista está firmemente instalada?

(28) Veja-se João Maria André, Renascimento e Modernidade. Do poder da magia à magia do poder, Coimbra, Livraria Minerva, 1987, pp. 76-95. A racionalidade maquinal resulta do cruzamento do construto matemático com o construto mecânico. Em termos mais precisos, esclarece o autor: «a verdade da máquina está na sua transparência total ao espírito humano, na possibilidade que o homem tem, de a desmontar e voltar a montar, de a des-construir e re-construir, passando a dominar totalmente a lei da sua construção, a razão da adequação de umas peças às outras", p. 84 .

${ }^{(27)}$ Veja-se a versão ampliada da Oração de Sapiência proferida na abertura solene das aulas da Universidade de Coimbra, no ano lectivo de 1985-86, Um discurso sobre as ciências, Porto, Edições Afrontamento, 1987.

(28) Michel Foucault, As palavras e as coisas. Uma arqueologia das ciências humanas. Tradução portuguesa de António Ramos Rosa com prefácios de Eduardo Lourenço e Vergílio Ferreira, Lisboa, Portugália Editora. s.d., p. 476.

(29) Trata-se do questionamento e abandono das concepções clássicas da matéria e da natureza: «Em vez da eternidade, a história; em vez do determinismo, a imprevisibilidade; em vez do mecanicismo, a interpenetração, a espontaneidade e a auto-organização; em vez da reversibilidade, a irreversibilidade e a evolução; em vez da ordem, a 


\section{Problemas actuais da História}

Mas não nos precipitemos e cinjamo-nos aos sinais emergentes da fase de transição em que se encontra o conhecimento científico pós-moderno. É visível que a história pede lições à física, mas também a física e a biologia pedem lições à história e às ciências humanas. "Para não irmos mais longe, quer a teoria das estruturas dissipativas de Prigogine quer a teoria sinergética de Haken explicam o comportamento das partículas através dos conceitos de revolução social, violência, escravatura, dominação, democracia nuclear» $\left({ }^{30}\right)$. Quanto à história, também não precisamos de recorrer a autoridades estrangeiras. Vejamos o que nos diz António Hespanha. Ao expor as razões do "anti-sistemismo" contemporâneo na prática historiográfica, o autor, por várias vezes, invoca a física como ciência exemplar: "Uma das condições de êxito das ciências físicas foi a formalização, com o que ela implica de univocidade de dados, de rigor dos conceitos e de automatismo dos processos de inferência (nomeadamente, no domínio do cálculo aritmético e algébrico, etc.)». É este o caminho que a história tem de tomar, o da "representação formalizada do saber» $\left({ }^{31}\right)$ ? Quer isto dizer que a tecnologia actual viabiliza a sonho de Condorcet $\left({ }^{32}\right)$ ? Então, talvez a história venha a renascer com outro nome ${ }^{(33}$ ) resultante duma enxertia entre história e matemática ou história e física - o que também não seria inédito!

Basta recordar a sociobiologia $\left({ }^{34}\right)$ : a biologia produzindo frutos sociológicos de tipo ideo-político, descendentes

desordem; em vez da necessidade, a criatividade e o acidente», Boaventura de Sousa Santos, Um discurso sobre as ciências, in ob. cit., p. 28.

(30) Idem, ibidem, p. 41.

(31) António Manuel Hespanha, «art. cit.», pp. 74-75.

(32) Veja-se Gilles-Gaston Granger, La Mathématique sociale du marquis de Condorcet, Paris, P.U.F., 1956; para uma visão mais alargada do matematismo social pós-iluminista, veja-se Georges Gusdorf, ob. cit., pp. 406-428.

(33) Recorde-se que Paul Veyne, há quase vinte anos perguntava: «L'histoire peut-elle devenir une géologie de l'évolution humaine?» (ob. cit., p. 181). A sua resposta é negativa. Este historiador pós-modernista defende que a verdade histórica não é "géométral", (ob. cit., p. 35). Refuta o modelo geométrico-fisicalista e todas as tentativas de reduzir a história a uma geologia (cf., sobretudo, pp. 168-179). Neste sentido escreve: «....une physique de l'homme est l'espoir de notre siècle, comme la physique a été celui du XVII e siècle. Mais l'histoire n'est pas cette science et ne le sera jamais», ob. cit., p. 9.

(34) Referimo-nos a E. O. Wilson, Sociobiology: The New Synthesis, Cambridge, Harvard Univ. Press, 1975; Idem, On Human Nature, 
directos do Léviathan hobbesiano $\left({ }^{35}\right)$, dos enunciados malthusianos e das leis bio-sociais criadas por Darwin e Spencer $\left({ }^{36}\right)$. Enfim, a ideologia victoriana reactualizada, hoje, por uma ciência dura $\left({ }^{37}\right)$. E se curiosamente, pela voz de alguns dos seus cultivadores, a sociobiologia está destinada a optimizar as relações sociais de acordo com as leis genéticas, também o cálculo das probabilidades na "matemática social» de Condorcet era colocado ao serviço da "perfectibilidade indefinida" do género humano; também a "física social» de A. Comte previa e prevenia o futuro positivo-normal-científico da Humanidade isto é, a instauração do regime sociocrático no Ocidente antevisto e preparado em todos os seus pormenores, incluindo os cálculos estatísticos: "Dois mil banqueiros, cem mil comerciantes, duzentos mil fabricantes e quatrocentos mil agricultores parecem-me fornecer bastantes chefes industriais aos cento e vinte milhões de habitantes que constituem a população ocidental. No pequeno número de patrícios achar-se-ão concentrados todos os capitais ocidentais, cuja activa aplica-

Cambridge, Harvard Univ. Press, 1978. A sociobiologia despertou no público um interesse acalorado pelas suas teses neo-darwinistas.

Tratando-se de uma obra técnico-científica, a sociobiologia alcançou uma invulgar popularidade. Na década de oitenta já constava dos programas do ensino secundário (veja-se o artigo de Ch. Davis). A revista Annales. Economies. Sociétés. Civilisations não foi indiferente ao "fenómeno». Na sua secção "Inter-sciences» em 1981 traz a lume um artigo de Chandler Davis, que expõe de modo sereno e crítico as teses da sociobiologia e suas implicações políticas. Ch. Davis, "La sociobiologie et son explication de l'humanité», Annales, 36e année, n. ${ }^{\circ}$, Juillet-Aôut, 1981, pp. 531-571.

(35) O Léviathan de Thomas Hobbes tem quase 338 anos. É um clássico do pensamento sub specie machinae que conhecerá um dos seus pontos altos na imaginosa obra L'Homme Machine (1748) da autoria do médico francês Julien Offray de La Mettrie. Com efeito, para Hobbes a sociedade é um grande homem-máquina sujeito ao mesmo determinismo mecanicista que comanda cada indivíduo singularmente considerado (Cf. Thomas Hobbes, Léviathan, Paris, Éd. Sirey, 1971, pp. 5-7). Uma visão desenvolvida do mecanicismo hobbesiano é apresentada por Raymond Polin, Politique et philosophie chez Thomas Hobbes, Paris, J. Vrin, 1977, pp. 1-80.

(36) Veja-se D. R. Oldroyd, Darwinian Impacts, an introduction to the darwinian revolution, The Open University Press, 1980, pp. 66-70; pp. 204243.

(37) Sendo vastíssima a bibliografia sobre as relações entre biologia-política, genética-ideologia, neurobiologia-política, etc., limitamo-nos a indicar uma obra que apresenta perspectivas diversificadas, ainda actuais: Albert Somit e outros, Biology and Politics. Recent Explorations, Mouton, The Hague, Paris, Publications of the International Social Science Council, by Maison des Sciences de l'Homme and Mouton, 1976. 
ção eles deverão dirigir livremente, sob a sua constante responsabilidade moral, em proveito dum proletariado trinta e três vezes mais numeroso" $\left({ }^{38}\right)$.

Com estas referências pretendemos, de modo fundamentado, colocar o seguinte problema: a sistematização formalizada do saber histórico abre o caminho e legitima a tentação cientista $\left({ }^{39}\right)$ que reduz ao determinismo mecânico-unidimensional a polivalência da historicidade sincrónia-diacronicamente considerada? Não se trata de afirmar que a cientificação do passado, na base dos modelos de inteligibilidade compatíveis com os sistemas informáticos, se traduza necessariamente numa particular vocação panóptica $\left({ }^{40}\right)$ das ciências históricas. No entanto, o arquivo de casos (científicos, literários, historiográficos ou outros) e mesmo de experiências históricas de sedução cientista-panóptica, "ortopédica" ou normalizadora é vasto desde finais do séc. XVIII. Hoje temos aí a tecnologia sociobiológica $\left({ }^{41}\right)$ ! A história também já

(38) Augusto Comte, Catecismo Positivista ou Exposição sumária da Religião Universal em onze colóquios sistemáticos entre uma Muther $e$ um Sacerdote da Humanidade. O Amor por Princípio. A Ordem por Base. O Progresso por Finalidade, trad. e notas de Fernando Melro, Publicações Europa-América, s.d., p. 207. Comte publicou o Catecismo positivista em 1851. É inegável que esta obra pretende ser a certidão de óbito científica dos ideais socialistas que confluiram na Revolução Republicana «democrática e social» de Fevereiro de 1848, na pátria do autor.

(39) De acordo com a definição de cientismo dada pelo Macmillan Dictionary of the History of Science, Edited by W. F. Bynum, E. J. Browne, Roy Porter, 1988, p. 381.

(40) A expressão em causa inspira-se em $O$ Panóptico de J. Bentham (1748-1842), obra editada em finais do século XVIII, a partir da qual M. Foucault criou o termo panoptismo para designar a física do poder-saber nas sociedades disciplinares modernas (1790-1810 a 1950, sensivelmente). Cf. Jeremias Bentham, El Panoptico, Madrid, Las Ediciones de la Piqueta, 1979, pp. 34-44; Michel Foucault, Surveiller et punir. Naissance de la prison, Paris, Gallimard, 1975, p. 196 e ss; 1dem, $A$ verdade $e$ as formas juridicas, Cadernos da Pontifícia Universidade Católica do Rio de Janeiro 1974, p. 69 e ss.; Idem, Résumé des Cours 1970-1982, Paris, Julliard, 1989, pp. 49-51; Gilles Deleuze, «Foucault, Historien du Présent», Magazine Littéraire, n. 257 , Septembre, 1988, p 51. Nesta base, tomamos o panoptismo como diagrama do cientismo historista que funcionaliza os princípios da circularidade e da transparência de acordo com a matriz benthamiana.

(41) Veja-se G. F. Sacarrão, A Biologia do Egoismo, Lisboa, Publicações Europa-América. s.d.; Pierre Thuillier, Les biologistes vont-ils prendre le pouvoir? La sociobiologie en question. 1. Le contexte et l'enjeu, Bruxelles, Ed. Complexe, 1981; T. Howard, J. Rifkin, Les apprentis sorciers. Demain la biologie, trad. francesa, Paris, Ramsay, 1979; M. Billig, L'internationale raciste. De la psychologie à la «science» des races, trad. francesa, Paris, François Maspero, 1981. 
sonhou com a posse de um saber a-histórico e definitivo, com um imperialismo gnosiológico e normativo pelo menos ao nível dos princípios orientadores dos resultados, sendo estes necessariamente tidos como parcelares mas não provisórios.

Porém, a vida e sobremaneira a experiência histórica não se deixam reduzir a uma mecânica, seja ela física, química ou outra. Por isso, o uso do termo prevismo é destituído de sentido nas ciências históricas e, em vez de lei, determinismo e previsibilidade seria mais justo dizer tendência normalizadora. Pois que outro ideal de objectivação pode ser perseguido por um saber cuja estrutura e consistência diferem profundamente dos sistemas experimentalistas hipotético-dedutivos? A que outro tipo de cientificidade é possível aspirar a não ser ao estabelecimento de um poder epistemológico normalizador do passado em função dos gostos, das carências e das necessidades do presente? Como entender de outro modo o ideal de história sem exterior para o qual aponta não só a sistematização formalizada dos materiais mas também o alargamento do campo de ideatos? Hoje, a historiografia não conhece fronteiras. Ela imprime história em tudo. Tudo historiciza, mesmo o que, aparentemente, não é histórico $\left({ }^{42}\right)$, desde a morte $\left({ }^{43}\right)$ e os rituais de finitude, à vivência do sagrado; desde a experiência da loucura ao amor - para registar precisamente aqueles domínios que, por serem universais em termos de cultura e filosoficamente experiências originais de sentido incondicionado, criam, na óptica do historiador actual, a ilusão de intemporalidade.

Outros sinais desta tendência normalizadora da história poderiam ser invocados. Neste sentido, não deixa de ser sintomático que, com frequência, se afirme a certeza da historici-

(42) Tomamos o histórico no sentido «caleidoscópico» - «positivista» proposto por Paul Veyne in ob. cit., pp. 226-241. Esta perspectiva assume epistemologicamente o primado da relação e seus efeitos constitutivos dos objectos históricos. Trata-se de uma leitura do histórico que comporta ecos estruturalistas mas não é um estruturalismo porque recusa o apriorismo formal e qualquer modelo uniforme de temporalização.

(43) Veja-se Fernando Catroga, «A cremação na época contemporânea e a dessacralização da morte. O caso português», Revista de História das Ideias, Coimbra, vol. 8, 1986, pp. 223-262. Importa notar que neste precioso trabalho o autor não absolutiza a perspectiva histórica e salvaguarda expressamente a irredutibilidade multisemântica da morte. Como se poderá verificar esta posição epistemológica aberta não limita o campo de visão do historiador. Pelo contrário, neste caso, os interesses da história conhecem uma protecção superior àquela que se julga obter com o ideal de história sem exterior. 
dade. Isto é: cientistas, literatos, filósofos e outros, todos concordam que, hoje, das raras certezas estabelecidas, apenas a evidência do tempo histórico oferece um nível de segurança óptimo. Isto significa, desde logo, o esquecimento de que a historicidade é uma «invenção recente»; uma verdade contemporânea das revoluções estruturais que irromperam na viragem do século XVIII para o século XIX no Ocidente. Esquece-se que ela tem uma idade, uma duração, um tempo de existência. Em suma, recalca-se a sua menoridade. Por isso, embora a historicidade seja relativa no espaço e no tempo, ela volve-se no absoluto que galvaniza os sentimentos religiosos do homem ocidental moderno que, pela mesma época, renunciou a Deus, como veremos adiante.

A história lida com a grande verdade mas isto não significa que ela possa responder à célebre pergunta do Livro XI das Confissões de Santo Agostinho. Pode no entanto significar ou melhor fundar a sua vontade de historicizar. A emergência de tantos objectos novos não será o sinal de um poder epistemológico que assim se mostra, se exerce, se reforça, que nada quer deixar escapar? Porque é que a história não está disposta a ceder algum resto do acontecer a outras disciplinas, em particular à sociologia que tradicionalmente se dedica ao presente $\left({ }^{44}\right)$, ao tempo imediato? A crítica severa que P. Veyne faz aos estudos sociológicos $\left({ }^{45}\right)$, não lhes reconhecendo o mínimo de valor, menos ainda de cientificidade, nem sequer o direito de existir, traduz o sentir autêntico das comunidades historiográficas?

Se assim for, estes dados podem ser tomados como provas duma tentação cientista, isto é, de uma estratégia panóptica que tem agora à sua disposição meios técnico-informáticos bastante promissores. É inegável que existe um modelo historiográfico que procura a máxima objectivação normalizadora do real: a visão integral e disciplinante da

(44) Veja-se B. Paillard, "Immédiate (Histoire)». in Dictionnaire des Sciences Historiques...., pp. 347-350; J.-P. Azema, "Temps présent», ibidem, pp. 653-656.

(45) Paul Veyne, ob. cit., p. 53 e pp. 187-196. Neste sentido, escreve o autor: "Il convient donc que les historiens prennent conscience que la sociologie est de l'histoire qu'ils négligent d'écrire et dont l'absence mutile celle qu'ils écrivent», p. 192. A história deve defender o seu território integralmente; deve quest:onar aquelas «devx pseudo-sciences, la sociologie et l'ethnographie, qui se partagent l'histoire des civilisations contempora:nes, l'une prennant celles des civilisés et l'autre celles des primitifs (Hérodote, plus c'airvoyant, décrivait conjointement la civilisation des Grecs et celle des Barbares)», ob. cit., p. 193. 
temporalidade em todas as suas dimensões; a manipulação consequente do ser pelo pensamento; o fim da interpretação, do comentário, das opacidades, das brechas, do indizível; não obviamente, via metafísica, à maneira de Hegel, mas através do algarismo numinoso (o platonismo volta sempre!). E o nome do real produzido por esta prática historiográfica optimista e altamente ritualizada é a normalização da memória segundo o traçado rigoroso dum fisicalismo óptico do acontecer. Com efeito, a partir do dispositivo do exame informático o historiador pode praticar uma observação sistemática, ordenada e hierarquizada. Este procedimento metodológico possibilita uma objectivação do real histórico supostamente transparente na medida em que os sinais produzidos pelo enorme volume de dados são de tipo estatístico, taxinómico, mecânico-causal. Julgamos, pois, que a extracção da verdade da história a partir de uma posição epistemológica deste tipo pode gerar uma nova forma de historismo cientista. E, se, por esta via, a história, ainda que "esmigalhada" puder erguer uma cidade manifestamente diferente da cidade caótica e fervilhante de Paul Veyne, então demonstrar-se-á a eficácia científica da formalização plena da história.

$\hat{\mathrm{E}}$ certo que o panoptismo ou modelo de cidade pestilenta $\left({ }^{46}\right)$ com os seus recortes, análises e repartições constitui a matriz das práticas sociais contemporâneas, incluindo as práticas científicas. Não é paradoxal que a história ainda faça excepção porque ela é, efectivamente, uma ciência diferente e não pode colocar-se ao lado das jovens ciências humanas, na verdade, muito jovens, comparadas com a História. Estas ciências, ditas moles, servem uma causa, a obsessão normalizadora, da qual são o efeito epistémico mais interessante. Elas nada têm a ver com a História neste sentido: não têm a mesma herança genética nem conquistaram qualquer relação de parentesco com a ciência-rainha. Todavia "elas não são o que outros denominam pelo nome bizarro de 'ideologia'» $\left({ }^{47}\right)$. Mas, a se a história não pensar seriamente o modo como se serve delas, designadamente da Antropologia, da Etnologia, da Psicologia e também de Economia, aparentemente mais pacífica, então, é possível interpretar o uso muitas vezes indiscriminado que ela faz de princípios, terminologias e valores «moles» como um fenómeno que põe em causa a diferença, autonomia e distinção da História.

(46) Cf. Michel Foucault, Surveiller et punir..., pp. 199-201.

(47) Michel Foucault, As Palavras e as coisas...,., p. 474. 
Não que ela perca a sua identidade. Pelo contrário, ao recorrer às ciências humanas, a história mantém viva a afirmação de que as determinações psico-sócio-antropológicas não podem sobrepôr-se à historicidade do homem. Assim, a história "cerca essas ciências de uma fronteira que as limita e arruina logo de início a pretensão que elas têm de valer no elemento da universalidade» $\left({ }^{48}\right)$ porque a objectivação do homem nas ciências humanas fica "limitada pelo ilimitado da História» $\left({ }^{49}\right)$. Mas, por outro lado, a emigração de conceitos e de enunciados das ciências humanas para a historiogratia e a sua circulação livre no território do historiador realiza a vontade expansionista de disciplinas que ocupam um lugar estranho no triedro dos saberes. Estranho, porque se abrem a todos os seus planos: não são ciências dedutivas como a matemática e a física mas aspiram à formalização; não são ciências empíricas como a biologia mas recorrem a modelos biológicos; e por fim, interferem com o campo filosófico. Daí a sua posição ambígua "que as faz parecer ao mesmo tempo perigosas e em perigo....: daí o perigo do 'psicologismo', do 'sociologismo' - do que se poderia chamar, numa palavra, o 'antropologismo' - que se torna ameaçador desde que, por exemplo, não se reflicta correctamente nas relações do pensamento e da formalização» $\left({ }^{50}\right)$. A História, mais do que qualquer outra ciência corre esse risco. Nele já se precipitou a biologia ao assumir-se como sociobiologia. Não se trata de um perigo imaginário. Veja-se, por exemplo, o ideal historiográfico de Jacques Le Goff. Ele exige a conversão da história da cultura numa antropologia histórica resultante dum estreitamento de relações entre história e etnologia. Textualmente: "l'anthropologie historique vise à une étroite collaboration entre histoire et ethnologie et à la longue à une fusion entre les deux disciplines que pourrait d'ailleurs rejoindre la partie non dogmatique de la sociologie» $\left({ }^{51}\right)$. Pode parecer surpreendente que o nome da nova ciência proposta não seja História mas Antropologia! Mas não admira, porque se trata de um tipo de fusão marcada pelo antropologismo. E não é notório que a transformação da História num adjectivo a desclassifica e a desfigura profundamente? 0 que resta do seu estatuto, da sua autonomia, da sua posição no quadro geral do saber,

(48) Idem, ibidem, p. 482.

(49) Idem, ibidem.

(50) Idem, ibiciem, p. 452.

(51) Jacques Le Goff in Objet et méthodes de l'Histoire de la Culture, Paris, Éditions du C.N.R.S., 1982, p. 247. 
uma vez alienada a sua identidade? Também não admira que o poder que, assim, é retirado ao histórico venha a emergir noutro lado. Justamente na "economia universal da natureza humana» ( ${ }^{52}$ ) como aponta Roger Chartier. A medida que o diferente e o novo são reduzidos à mesmidade ou que o histórico é subalternizado e vazado numa identidade indiferente, o "paradigma perdido» de que falava Edgar Morin tende a instalar-se e a sobrepor-se à própria historicidade. O fundamental torna-se irreconhecível. Contudo, Jacques Le Goff assume este perigo. Ele é claro ao dizer que «l'anthropologie historique s'intéresse à l'homme tout entier à l'intérieur des sociétés historiques globales. Elle étudie, selon le programme de Michelet dans sa préface de 1869 à l'Histoire de France qu'il est à peine besoin de moderniser, aussi bien l'histoire matérielle que l'histoire morale des sociétés, l'histoire du biologique que l'histoire de l'imaginaire. C'est une histoire totale» $\left({ }^{53}\right)$. Ou antes: é uma antropologia total. Recorde-se que a sociologia de A. Comte, como se verá adiante, também era uma história total e um antropologismo perfeito. Mas há aqui uma diferença pertinente: é que a sociologia pelo menos na sua dimensão jurídico-formal e institucional não perdia a sua identidade: enquanto que Jacques Le Goff sendo historiador e não antropólogo propõe uma história total chamada Antropologia! Porquê esta conversão da ciência histórica em Antropologia? Sabe-se que o historiador francês procurou pensar a cientificação progressiva da história evitando o perigo de economicismo. Mas o futuro que idealizara para esta ciência não está isento de escolhos graves. Basta pensar na recuperação do "conceito clássico de natureza humana" $\left.{ }^{54}\right)$ como bem viu Philippe Ariès, ou no valor que é atribuído à "economia universal da natureza humana» segundo a crítica de Roger Chartier. Não será também legítimo supor que esta fusão da história e da etnologia numa disciplina nova, a Antropologia histórica, abre caminho à reedição dos universais da filosofia idealista-psicologista da história?

Assim, também pelo que deixamos aqui alinhavado, impõe-se fazer uma anatomia minuciosa dos contactos que a história trava com as ciências humanas, não só ao nível dos

(52) Roger Chartier, A História Cultural entre práticas e representações, Lisboa, Difel, 1988, p. 79.

(53) Jacques Le Goff in Objet et méthodes...., p. 247.

(54) Ph:lippe Ariès, «La sensibilité au changement dans la problématique de l'historiographie contemporaine», in Certitudes et Incertitudes de l'Histoire sous la direction de Gilbert Gadoffre, Paris, P.U.F., 1987, pp. 169-174. 
conceitos, proposições e modelos mas também ao nívei dos objectos. Particularizando: é o caso da morte e da festa, entre outros, domínios habituados ao olhar do etnólogo mas que recentemente conheceram um investimento historiográfico fecundo. A historicização da festa pode parecer um paradoxo "puisque la fête trouve sa référence dans un âge d'or qui la maintient en quelque sorte hors de l'histoire, dans un cycle calendaire, un renouvellement perpétuel qui est la négation de la mobilité et presque de la mort" $\left({ }^{55}\right)$. Mas, é justamente por isso que a objectivação da festa em termos históricos produz efeitos teóricos consideráveis: mantém aberto o problema da natureza da temporalidade; exige do historiador uma reflexão cuidada sobre o tempo linear, o tempo das descontinuidades e o tempo cairológico; impõe o questionamento das categorias universais, da ilusória invariância dos objectos históricos; obriga-o a estar atento ao perigo da "antropologização" da escrita da história que se traduz pela possível emergência do homem universal no centro do discurso, pela posição de soberano fundador que ele facilmente assume apesar da revolução coperniciana operada na ciência histórica por Karl Marx.

A história tem o direito de perseguir ideais de cientificidade, tem o direito de "inventar» novos objectos, de incorporar em si domínios que são familiares a outras disciplinas. Mas daí decorre o imperativo de esclarecer e reafirmar a sua originalidade e a sua diferença sobretudo em relação às ciências humanas. É inegável que o contacto com estas disciplinas se revela extremamente fecundo para a história mas também lhe coloca problemas muito sérios sobretudo quando se trata da etnologia e da psicanálise dado que as ambições totalizantes destas chocam com a vocação totalizadora da própria história. E, se, à partida, esta se encontra numa posição epistémica privilegiada. mais facilmente do que aquelas pode ser levada a sonhar com a transparência geométrica atravessada de jogos relacionais hierárquicos, isto é, com "l'utopie de la cité parfaitement gouvernée» $\left.{ }^{56}\right)$. Dizendo de outro modo, o interesse historiográfico pela objectivação total do acontecer é reavivado pelas práticas interdisciplinares, ainda que equívocas, e encontra no potencial do "sistemismo»

(55) Pierre Nora in Raymond Bellour. Le livre des autres. Entretiens, Paris, Union Générale d'Éditions, 1978, p. 336. Sobre a objectivação histórica da festa veja-se Mona Ozouf, La fête révolutionnaire 1789-1799, Paris, Gallimard, 1976.

(58) Michel Foucault, Surveiller et punir...., p. 200. 
informático a via segura para a sua prossecução. É este o sonho de alguma historiografia e não há motivos para censurá-lo. Pois, que negatividade seria possível extrair do poder efectivo de atravessar com o olhar panóptico o passado, o presente e o futuro, do poder de viajar no tempo e ancorar o pensamento num cais renascentista como numa cidade movente no espaço infinito do ano 19290 ?

Pelo contrário, talvez a visão do futuro mesmo em termos probabilísticos produzisse efeitos surpreendentes no modo de viver, de comunicar, de existir, de escrever a história $\left({ }^{57}\right)$. Seria outra a experiência de mundo, de sentido, de absurdo? A panoptização real do tempo talvez provocasse um questionamento consequente das múltiplas faces das condições existenciais da humanidade. Mas isto é precisamente o indizível. Importa que nos calemos, assim ensinou Heidegger $\left({ }^{58}\right)$. Portanto convém fixarmo-nos simplesmente nisto: mesmo com cálculos, axiomas, tendências, probabilidades, estatisticas, a historicidade ${ }^{59}$ ) permanecerá abertura imprevisível isto é, excesso, inquietude, errância, poder de derramar todas as escatologias e ficções científicas. É por isso que, à semelhança de Sísifo, a humanidade tem de reescrever incessantemente a sua história, já que a chegada do novo e do diferente desconstrói, envelhece e apaga a memória herdada. É o que nos diz de modo excelente José Mattoso: «Não há História definitiva, pela simples razão de que a palavra pronunciada, por mais fundadora e fecunda que seja, está, ela própria, sujeita ao tempo, torna-se ela própria passado. objecto de outras experiências. o que quer dizer que tem de ser constantemente renovada, constantemente pronunciada para se manter viva" $\left.{ }^{60}\right)$.

Contudo, é inegável que a formalização imprime à palavra da história uma consistência superior: a força interna do número e das figuras geométricas que, de resto, têm tanta dignidade poética como as palavras. E sabido que os benefí-

${ }^{57}$ ) Paul Veyne pensa de modo diferente e afirma num sentido oposto: «....savoir quel sera l'avenir de l'humanité ne nous amènerait nullement à modifier notre façon d'écrire l'histoire du passé", ob. cit., p. 31 .

(58) Martin Heidegger, (Sein und zeit. 1927). Consultámos L'Ftre et le temps, trad. R. Boehm et A. de Waelhens, Paris, Gallimard, 1964, pp. 164-165.

${ }^{(59)}$ Sobre a genealogia do termo historicidade veja-se Miguel Baptista Pereira, Originalidade e Novidade em Filosofia. A propósito da experiência e da história. Separata de Biblos, LIII. Homenagem a Victor de Matos e Sá, Coimbra, 1977, fundamentalmente, pp. 25-33.

$\left.{ }^{60}\right)$ José Mattoso, ob. cit., p. 29. 
cios resultantes da aplicação da informática à história são diversos e situam-se a vários niveis do trabalho do historiador: desde a elaboração de bases de dados documentais até às bases de dados heurísticos; desde as estatísticas ao tratamento automático dos textos. Para a história político-cultural esta última possibilidade impõe uma ruptura com a exegética tradicional. Em termos simplistas dir-se-ia que o tratamento automático do texto equivale à morte do comentário porque a linguagem é tomada como objecto ou coisa imediata e manifesta; o texto não esconde sentidos latentes ou segredos apenas decifráveis pela entrada em cena do autor; a linguagem não diz algo diferente do que mostra na sua materialidade totalmente visível. Assim, espera-se que a organização lexical e semântica do texto se funda na positividade que lhe é própria sem mediações transcendentais ou subjectivas. Será talvez o fim da alegoria por um lado e da interioridade da obra referida ao seu autor, por outro lado. Mas, é cedo demais para avaliar os resultados científicos e os efeitos epistemológicos dos novos caminhos abertos pela ordem informática, neste campo particular.

Para o problema da relação da história com a sua actualidade

Gostaríamos de acrescentar a todas as razões de ordem científica que reclamam a sistematização do saber histórico, o interesse do historiador pela sua própria actualidade. O recurso da historiografia à informática prova, só por si, que o historiador vive no presente e não quer furtar-se a ouvir os seus apelos.

A história tem interesses científicos a defender e como qualquer outra ciência procura acumular vantagens recorrendo a meios que lhe trazem benefícios. Ao adoptar estratégias metodológicas informáticas, a história está a criar a expectativa de que este investimento proporciona além do seu desenvolvimento interno, o reforço da sua posição no quadro geral do saber. Reforço urgente, pois o estatuto da história na actual civilização técnica dá que pensar. A história nãc pode permitir que outros poderes-saberes a reduzam a um jardim de curiosidades exóticas como se o presente não estivesse impregnado de passados recentes e longínquos, como se a história não tivesse o direito e o dever de se pronunciar sobre a sua actualidade e de se gravar na fisionomia cultural 
do presente. Já se tem dito que a história hoje não pode, só por si, construir a identidade de uma nação. A auto-imagem de um povo parece não depender basicamente da singularidade da sua memória mas do relacionamento comparativo entre as diferentes comunidades nacionais, o que significa que o olhar antropológico se sobrepõe ao album historiográfico. Jacques Le Goff confessa isto mesmo sem equívocos, ao dizer: "La souveraineté de l'historiographie a été dépassée par le mouvement même de l'histoire. Ce n'est plus principalement dans la confrontation avec son passé qu'une société se cherche et se trouve, mais plutôt dans le contact avec les autres sociétés. La conscience de notre présent n'est plus prioritairement historique, mais anthropologique» $\left({ }^{61}\right)$. Se o presente não exige que a história responda a esta necessidade cultural básica isto não quer dizer que tenha chegado a hora da verdadeira história pela história, do jogo erudito gratuito ou do conhecimento como fim em si mesmo. Mas significa, pelo contrário, que novos desafios the são colocados e que o historiador deve estar atento à sua actualidade isto é, ao presente que traz em si o futuro. Noutros períodos historiográficos, designadamente na fase positivista, o historiador soube estar vigilante e soube defender a história perante as mutações epistémicas que então se operavam, como iremos ver.

Hoje, mais ainda do que na idade moderna (de 1790-1810 a 1950) $\left({ }^{62}\right)$ importa que o historiador não se aliene da sua actualidade. Em primeiro lugar, não se pode fazer tábua rasa da dívida que o historiador tem relativamente ao seu tempo e será no mínimo uma questão de bom senso retribuir aquela oferta ôntico-epistémica. Usar bem a razão como diria Descartes ou ousar pensar como proclamou Kant é a maneira mais justa de comunicar com o presente. Sabe-se quanto Pierre Vilar, Jacques Le Goff, Pierre Nora, René Rémond, Paul Veyne, Michel Foucault e outros, têm insistido na necessidade de não se abandonar o presente. de não o entregar desinteressadamente à filosofia e às ciências humanas porque, além do mais, o conhecimento do presente é fundamental para compreender o passado. A actualidade, isto é, a historicidade do que está aí, do sendo, tem vindo a ser pensada desde a segunda revolução coperniciana de Kant até aos trabalhos da Escola de Frankfurt passando por Hegel, Nietzsche e pela reflexão weberiana. Mas isto não significa que a pergunta por

(61) Jacques Le Goff in Raymond Belour, ob. cit., p. 330, (sublinhado nosso).

(62) Michel Foucault in Raymond Bellour, ob. cit., p. 124. 
aquilo que está ocorrendo no presente fique esgotada pela procura incessante e sistemática do filósofo. Em cada momento ela renasce por toda a parte, especialmente no decurso da prática historiográfica. Então, o historiador não deve sufocá-la, antes tem obrigação de a receber isto é, de a ouvir e de devolver ao seu tempo uma resposta, nem que seja sob a forma de uma descodificação prenunciativa dos dados históricos. A este propósito, tomemos como exemplo a sugestão de Pierre Vilar: "Pense em toda a História de que fomos testemunhas e de que tantos homens foram vítimas. Pense no nazismo em relação à Alemanha de Guilherme II, na crise de 1929 em relação às crises do século XIX em Auschwitz em relação ao czarismo, na Segunda Guerra Mundial em relação às expedições coloniais. A escala do nosso século de ferro, a História não cessa de repetir-se.... ela faz uma grande quantidade de borrões, e de cada vez é um pouco mais trágica" $\left({ }^{63}\right)$. Visão pessimista, é certo. Mas o que importa é que ela representa a coragem de arriscar um juízo, a vontade de, por si mesmo, construir uma intelecção do sentido da história. Uma - entre outras - de acordo com a multiplicidade de perspectivas características do saber histórico. O que importa, disse-o Kant. é ultrapassar a menoridade que adormece a razão humana; é ter coragem de pensar sem a direcção de outrem: «Sapere aude! aie le courage de te servir de ton propre entendement» $\left({ }^{64}\right)$.

$\mathrm{Na}$ verdade, desde que Kant acordou dos «sonhos da metafísica" pela leitura de Hume e instituiu o "tribunal da razão» em 1781, criou a possibilidade de algum tempo depois, em circunstâncias de grande tensão histórica e filosófica, lançar o problema do ser actual $\left({ }^{65}\right)$. Ao responder, em 1784, à pergunta: "o que são 'as luzes'?», Kant afirmava o valor do tempo presente, a necessidade de se pensar o acontecer actual com firmeza, imaginação criadora e capacidade decisória. Assim se abria o caminho para que também a história assumisse a sua pertença ao tempo presente que já está aí e continuamente vem chegando. Para explicitar melhor, socorramo-nos da palavra filosófica: "Ao chamar 'revolução' ao novo

(63) Pierre Vilar in Jacques Le Goff, Le Roy Ladurie, Georges Duby e outros, A Nova História, Lisboa, Ed. 70, 1978, p. 68.

(64) Kant «Réponse à la question: Qu'est ce que 'les lumières'?», in La Philosophie de l'histoire, trad. S. Piobetta, Paris, Aubier-Montaigne, 1947, p. 83.

${ }^{(65)}$ Vejam-se os prefácios à primeira (1781) e à segunda (1787) edições da Crítica da Razão Pura. Consultámos a trad. francesa, Critique de la raison pure, Paris, Flammarion, 1976, pp. 29-55. 


\section{Revista de História das Ideias}

conceito de razão, Kant situa-o imediatamente na realidade histórica do pensamento europeu e, por isso, além do tempo da experiência científica, há uma co-afirmação do tempo histórico» $\left.{ }^{66}\right)$.

Do mesmo modo, se ao compreender a sua historicidade, a história não pode alimentar a ilusão cientista de conhecer teleologicamente o desenrolar dos acontecimentos, assumindo-a pode alcançar "o máximo de consciência possível" (Goldmann) e produzir efeitos oportunos na episteme do seu tempo.

Foi justamente esta coragem de ser contemporânea do seu presente que singularizou valorativamente a historiografia positivista ${ }^{\left({ }^{77}\right)}$. Referimo-nos, em particular, à escrita da história praticada por Fustel de Coulanges $\left({ }^{68}\right)$; aos trabalhos de Gabriel Monod e Gustave Fagniez, fundadores da Revue Historique em $1876{ }^{\left({ }^{69}\right)}$; à concepção de história instituída pela obra de Charles-Victor Langlois e Charles Seignobos, Introduction aux études historiques $\left({ }^{70}\right)$, que vigorou pelo menos até à fundação da Revista Les Annales ( ${ }^{71}$ ) em 1929. Com efeito, a historiografia positivista-metódica, dentro dos sofia...., p. 18

(66) Miguel Baptista Pereira, Originalidade e Novidade em Filo-

(67) Veja-se José Amado Mendes, ob. cit. pp. 66-74.

(68) Veja-se Charles-Olivier Carbonell, Histoire et historiens. Une mutation idéologique des historiens français 1865-1885, Toulouse, E. Privat Editeur, 1976, pp. 319-323; Georges Lefebvre, La naissance de l'historiographie moderne, Paris, Flammarion, 1971, pp. 217-222.

(69) Veja-se Ch.-O. Carbonell, ob. cit., pp. 409-451. A Revue Historique foi a tribuna de uma escola historiográfica positivista republicana e protestante, rival da escola católica e realista que tinha como órgão a Revue des Questions Historiques, fundada em 1866 por G. du Fresne de Beaucourt. É verdade que esta escola ultramontana e legitimista, tendo como pai espiritual Joseph de Maistre, se pretendia científica e fazia declarações metodológicas de tipo positivista tais como: cingir-se aos «factos", às "fontes originais", exercer a "crítica». Mas não é uma escola positivista no sentido rigoroso do termo pois funda a inteligibilidade histórica no providencialismo teológico e cultiva a erudição enquanto meio de repor a verdade católica e monárquica. Cfr. Ch.-O. Carbonell, ob. cit., pp. 325-399. de 1898.

${ }^{(70)}$ A primeira edição é dada à estampa em Paris no ano

(71) Les Annales d'Histoire Économique et Sociale, revista fundada por Marc Bloch e Lucien Febvre. Mas, a revolução dos Annales não pôs em causa as exigências científicas básicas formuladas pelo positivismo e que ainda hoje constituem a base fundamental do desenvolvimento dos estudos históricos. A sua fraca implantação em Portugal condicionou o avanço da nossa historiografia. Neste sentido, não é possível duvidar da exactidão do quadro traçado por José Mattoso in A Escrita da História...., p. 110. 
seus limites epistémicos, soube estar atenta ao seu tempo o que lhe permitiu defender os interesses historiograficos evitando, nomeadamente, a sua absorção pela jovem sociologia.

Ao recusar o dogmatismo cientista à maneira de Comte $\left({ }^{72}\right)$ e a filosofia idealista da história instituída por Hegel, a historiografia positivista afirmava a irredutibilidade da História a códigos meta-históricos. Nesta base, tornou-se possível historicizar a imagem da humanidade que se viu despojada de sentido com a fragmentação da unidade epistémica "clássica». A "grande narrativa comum às coisas e aos homens", diz a prosa foucauldiana, "achou-se fracturada no início do século XIX, na grande viragem da episteme ocidental.... As coisas receberam primeiro uma historicidade própria que as libertou desse espaço contínuo que lhes impunha a mesma cronologia que era imposta aos homens.... A natureza já não lhe fala da criação ou do fim do Mundo, da sua dependência ou do seu próximo julgamento. Ela já não fala senão de um tempo natural. As suas riquezas já não lhe indicam a antiguidade ou o retorno próximo de uma idade de oiro, já não falam senão das condições de produção que se modificam na História; a linguagem já não traz as marcas de antes de Babel ou dos primeiros gritos que ressoaram na floresta; as suas armas são as da sua própria filiação. O ser humano já não tem história; ou antes, uma vez que ele fala, trabalha e vive, acha-se, no seu próprio ser, inteiramente misturado a histórias que não lhe são nem subordinadas nem homogéneas» $\left.{ }^{73}\right)$. Assim ao entrar no séc. XIX a cultura ocidental está preparada para derramar sobre si mesma a "morte de Deus» e extrair efeitos inovadores do recalcamento do nihilismo daí resultante. Este fenómeno seria anunciado por Nietzsche mais tarde, no célebre monumento filosófico "der tolle Mensch" da obra Die fröhliche wissenchaft (1882), monumento que a voz do seu Zaratustra (1883-85) havia de eternizar.

Com efeito, a laicização material do saber nas e pelas «ciências empíricas» emergentes (Biologia, Economia e Lin-

(72) Por isso se exclui deste campo historiográfico o discípulo de A. Comte, Louis Bourdeau, autor da obra L'histoire et les historiens, essai critique sur l'histoire considérée comme une science positive, Paris, Félix Alcan, 1888. O seu ideal científico procede do campo adversário da estratégia metódico-positivista defendida por G. Monod, E. Lavisse, Langlois, Seignobos e outros. Cfr. G. Bourdé e H. Martin, Les écoles historiques, Paris, Seuil, 1983, p. 162; Ch.-O. Carbonell, ob. cit., pp. 402-408.

(73) Michel Foucault, As Palavras e as coisas...., pp. 477-479. 
guística) apagava o continuum pré-estabelecido, a ordem, a representação, os lugares e tempos sagrados, a vontade divina, a criação do mundo, a idade de oiro, Babel. Ao perder esta memória erguia-se, então, para o homem ocidental a necessidade de recompor a história a partir dos factos positivos. Foi esta missão que a historiografia positivista cumpriu, respondendo com a sua febre de documentos, de dados, factos, positividades em suma. à dilacerante finitude do homem decorrente da decomposição do Criador. É pois legítimo afirmar que a morte de Deus instituiu as condições que tornaram possível e necessária a emergência da História em moldes positivistas. Por isso, a escrita da história conheceu um renascimento e a sua estratégia de reconstrução de uma memória positiva cheia de puros acontecimentos, de empiricidades ainda hoje se deixa reconhecer $\left.{ }^{\left({ }^{74}\right.}\right)$. E, desta forma, ao mesmo tempo que trespassa, evidencia a finitude dos homens, a sua condição de órfãos pelo crime cometido, a sua queda implacável, enfim. o seu errar, a sua solidão, a sua estranheza. Mas talvez a historicidade seja ainda a sublimação do sagrado, a verdade que convém a um mundo que precisamente neste mesmo período vive profundas convulsões estruturais. $\mathrm{Na}$ época da morte de Deus, que ainda é a nossa, a História assumiu reconstruir a imagem do homem inscrevendo no mais profundo do seu ser a verdade limitada mas aberta da sua factualidade histórica, isto é, da sua exposição ao acontecimento.

Seria um erro não ver que além da morte de Deus muitas outras mortes e vidas contribuíram para vulcanizar o grande rejuvenescimento da historiografia no último quartel do século XIX. Não foi só por causa dos gritos e dos risos daqueles que não acreditavam em Deus ou das perplexidades do "insensato" nietzscheano que o homem se viu esvaziado da narrativa histórica que unia a criatura ao criador. Não foi só a emergência da Biologia, da Economia e da Filologia que quebrou o espaço uno da episteme clássica e fez sentir ao homem que as coisas se desvinculavam dele. Não foi só porque abandonado (no espaço epistémico) pela natureza, pela vida, pela linguagem e pela riqueza, que o homem se sentiu perdido e sem memória na civilização ocidental marcada para sempre pela Grande Revolução Francesa.

(74) Veja-se R. C. Collingwood, The Idea of History, Oxford, The Clanderon Press, 1946, p. 223. 
A prosa epistémica tem de fundir-se na ordem-desordem $\left({ }^{75}\right)$ material da existência e o que aqui encontramos é uma empiricidade recente: o capital no quotidiano de homens concretos que trabalham, falam e vivem de formas acentuadamente desiguais. Assim, a desistoricização vivida pelo ocidente com o desagregar do corpo económico-social e político-mental do antigo regime, bem como a emergência da descrição histórica feita de entes singulares, de datas, de episódios que falam só por si, reduzidos à sua consistência material, ambas têm um solo comum. Trata-se, obviamente, da dinâmica do modo de produção capitalista $\left({ }^{76}\right)$ que desenraizou os homens concretos das suas tradicionais condições de existência tanto físicas como sócio-culturais. Pois, a história teve a consciência aguda do eclipse do tempo e exerceu o direito de devolver à humanidade a memória que se esvaecia naquilo que era absolutamente irreconhecível, porque novo de raíz: a revolução industrial-burguesa intrincada nos meandros da explosão demográfica-urbanística que imprimiu uma metamorfose profunda na identidade sócio-mental dos povos.

E inquestionável que o séc. XIX fracturou, expandiu e revolucionou os quadros clássicos da razão e da vida; introduziu o novo, o inédito na experiência do tempo e do espaço; criou novas regras nas relações sociais; uma nova lógica institucional e política; novos modos de afirmar o corpo e a existência - basta passar em revista os testemunhos literários de E. Zola, de V. Hugo ou de Ch. Dickens que nos são mais familiares. E igualmente certo que renunciou a Deus pois é esse não que inspira a decomposição filosófica do criador em obras como as de David Strauss, Feuerbach, Marx e Haeckel, para nos limitarmos ao solo germânico de Nietzsche.

Igualmente se pode reconhecer que também ao nível das empiricidades quotidianas, se conjugam um não a Deus com um sim à vida. Mesmo quando se trata da morte, o séc. XIX faz dela um instrumento da vida, torna-a útil, dessacraliza-a, aprende a geri-la, incorpora-a no jogo dos interesses existenciais. Seja o cadáver: ente impregnado de verdades que dele são extraídas pelas ciências biológicas e médicas. Seja o corpo morto do revolucionário: ente irradiante de vontade de viver

(75) Categorias de Edgar Morin para uma teoria fisicalista da sociedade ou mais explicitamente termodinâmica. Veja-se Sociologia. A sociologia do microssocial ao macroplanetário, Publicações Europa-América, s.d., pp. 60-77.

(76) Veja-se, entre outros, Charles Morazé, Les bourgeois conquérants, Paris, Librairie Armand Colin, 1957. 
que expõe imediatamente aos olhares o direito a uma vida fisicamente suportável. Seja a revolução: pois, este é «o tempo das revoluções» $\left({ }^{77}\right)$ e dizer revolução é dizer morte, vida, excesso, isto é, irrupção do novo e fragmentação da memória.

É também possível dizer que o séc. XIX manchou profundamente e quase tornou irreconhecível o sangue azul e a sua simbólica. Mas, não lhe opôs um sangue amorfo nem nivelador, nem ainda uma corrente sanguínea feita de igualdade, liberdade e fraternidade. Antes, inventou uma tecnologia complexa pela qual a burguesia afirmava o seu «bio-poder»: o poder de inserir os corpos na mecânica da produtividade, o poder produtor do próprio indivíduo mas também da sua desindividualização.

Em termos foucauldianos: "l'homme occidental apprend peu à peu ce que c'est que d'être une espèce vivante dans un monde vivant, d'avoir un corps, des conditions d'existence, des probabilités de vie, une santé individuelle et collective, des forces qu'on peut modifier et un espace où on peut les répartir de façon optimale» $\left({ }^{78}\right)$. Este sim à vida (hoje já é possível dizer qualidade de vida) tem uma complexidade própria nas sociedades oitocentistas que não podemos agora desenvolver. Mas importa aqui sublinhar que a sua positividade é entretecida pela dessacralização da morte, pela experiência da finitude, pelo abandono da transcendência - em suma, pela morte de Deus.

Ora, tudo isto é o outro lado da prosa historiográfica empirista, positivista, da historicização no espaço puro e nu

(77) François-G. Dreyfus, Le temps des révolutions, 1787-1870, Librairie Larousse, 1968.

(78) Michel Foucault, Histoire de la sexualité 1. La volonté de savoir, Paris, Gallimard, 1976, p. 187. O «bio-poder» na civilização ocidental (sécs. XIX-XX) é tratado fundamentalmente no cap. V «Droit de mort et pouvoir sur la vie». Sobre esta hipótese foucauldiana veja-se Antoine Griset, "Foucault, um projecto histórico», in Jacques Le Goff, Le Roy Ladurie, Georges Duby e outros, A Nova História...., pp. 71-79.

A hipótese do «bio-poder» inscreve-se numa teoria do poder mais vasta: uma nova economia de relações de poder que reavalia criticamente os limites do modelo jurídico (o problema da legitimidade e da legalidade) e do modelo institucional (o estado e os seus aparelhos). Vejam-se, sobre esta temática, Alan Sheridan. Michel Foucault. The will to truth, London and New York, Tavistock Publications, 1980, pp. 113-226. O autor defende que «Foucault's 'political anatomy' constitutes a radical break with all previous conceptions of power» (p. 218), incluindo a teoria marxista (pp. 221-222). No mesmo sentido se pronuncia Gilles Deleuze: "C'est comme si, enfin, quelque chose de nouveau surgissait depuis Marx", in "Ecrivain non: un nouveau cartographe. Michel Foucault: Surveiller et punir», Critique, Paris, Tome XXXI, n. 343, Décembre 1975, p. 1212. 
da cronologia, no tempo vazio de transcendências. Assim, defendemos que a história factual respondeu de uma forma nobre e erudita aos desafios do seu tempo, embora a febre de factos não seja só por si o modo ideal de dar conta da sua historicidade. $O$ positivismo historiográfico deu ao seu presente uma memória vital e projectiva envolvendo em si mesma o seu próprio ser actual como o testemunha, desde logo, a lição ${ }^{79}$ ) do grande mestre Charles Seignobos.

Para reforçar as bases desta perspectiva, isto é, para melhor se compreender o renascimento positivista dos estudos históricos importa ainda considerar os efeitos provocados por uma jovem disciplina na episteme moderna: a sociologia. Sabe-se que a mutabilidade social característica do industrialismo burguês liberal e demoliberal proporcionou a emergência do olhar sociológico. Como escreveu Amadeu Carvalho Homem «o advento da grande indústria contemporânea.... converteu a Europa num verdadeiro laboratório de análise social» $\left({ }^{80}\right)$; ou nas palavras de Fernando Catroga "....pode dizer-se que a Sociologia é filha do industrialismo: $\left({ }^{81}\right)$. Coube à França introduzir esta ciência no quadro geral do saber o que se compreende se atendermos ao modo particular como o industrialismo burguês se implantou na sociedade francesa e sobretudo à singularidade paradigmática da Revolução Francesa de 1789.

Consideramos que A. Comte é o pai legítimo da sociologia, termo que ele próprio criou unindo uma raiz latina com uma raiz grega. E verdade que a Fisiologia social de Saint-Simon $\left({ }^{82}\right)$, concebida sob o signo da lei newtoniana foi muito importante para a emergência desta nova ciência. Mas, ela nasce justamente em 1839 na 47. ${ }^{\text {a }}$ lição do Cours de Philosophie Positive $\left({ }^{83}\right)$. Sabe-se que a sociologia era portadora de

(79) Veja-se J. Glénisson, «Seignobos, Charles, 1854-1942», in Dictionnaire des sciences historiques, pp. 630-631.

(80) Amadeu Carvalho Homem, Ideologia e Indústria. A exposição distrital de Coimbra de 1884, Separata da Revista de História das Ideias, vol. 6, Coimbra, 1984, p. 395.

(81) Fernando Catroga. Os Inícios do Positivismo em Portugal. o seu significado político-social, Separata da Revista de História das Ideias, vol. 1, Coimbra, 1977, p. 3.

1969 , pp. $37-39$.

$\left.{ }^{82}\right)$ Veja-se Pierre Ansart, Marx et l'anarchisme, Paris, P.U.F.,

(88) Veja-se Oeuvres d'Auguste Comte, Paris, Anthropos, 1969, t. IV, pp. 200-201. A constituição da Sociologia preocupou o autor desde muito cedo e isso é já notório em 1822 no célebre Plan de travaux scientifiques nécessaires pour réorganiser la société, obra da fase de pré-ruptura com Saint-Simon, inserta posteriormente no apêndice geral do Système de Politique Positive ou Traité de Sociologie instituant la Religion de l'Humanité, 4 vols., Paris, Mathias, 1851-1854. 
uma inegável vontade de expansão teórica e prática que, de resto, ainda hoje manifesta. Com efeito, mesmo antes de nascer, já vinha provocando um desequilíbrio na episteme de oitocentos. Tinha então um nome duro - Física social - que revela, desde logo, vontade de atingir o máximo de rigor científico, de formular leis exactas, de prever o futuro do Ocidente. Depois do seu nascimento estas pretensões científicas e tecnológicas não se modificaram. Pelo contrário, foram-se acentuando e culminaram num Catecismo positivista, num Apelo aos conservadores e numa Síntese subjectiva $\left({ }^{84}\right)$, dando cumprimento inequívoco ao modelo mais acabado de cientismo $\left(^{85}\right)$. Esta ciência, ainda criança, dizia ser a ciência das ciências; a última das ciências sob o ponto de vista histórico; a primeira, sob o ponto de vista lógico-formal, pois a ela competia hierarquizar, unificar e articular num sistema definitivo, o conjunto das ciências. A Sociologia ao pretender identificar-se com a verdade absoluta, tomava-se como sendo a única ciência capaz de inteligir e dar sentido às verdades parciais e aos erros transitórios, ditos necessários, do passado e do seu presente. Auto-concebia-se a exclusiva detentora das leis do tempo passado, presente e futuro e único poder gestor da história em harmonia com a invariabilidade das leis, ditas, naturais. Não admira, pois, que a história tenha sido a disciplina mais atingida pelas frequentes incursões que a física social fazia no seu campo, há muito estabelecido.

Com efeito, ao pretender sob um olhar panóptico objectivar a totalidade do real social, tanto sincrónica como diacronicamente, a jovem ciência apropriava-se do território do historiador, convertia-o numa parte da sociologia - a dinâmica social $\left({ }^{86}\right)$ e simultaneamente subordinava a própria

(84) Vejam-se Catéchisme positiviste ou Sommaire exposition de la religion universelle en onze entretiens systématiques entre une femme et un prètre de l'humanité, Paris, Ed. do autor, 1851; Appel aux conservateurs, Paris, ed. do autor, 1855; Synthèse subjective ou Système universel des conceptions propres à l'état normal de l'humanité, Paris, ed. do autor, 1856.

(85) Na perspectiva do Macmillan Dictionary of the History of Science A. Comte construiu um cientismo perfeito que converteu «....into a technocratic ideology for industrial society....", p. 381. Uma posição diferente é estabelecida por Georges Gusdorf que considera o cientismo uma doutrina pós-comtiana cujo representante típico é F. Le Dantec. Veja-se Introduction aux sciences humaines, Paris, Editions Ophrys, nouvelle édition, 1974, pp. 343-364.

(86) Veja-se do Cours de Philosophie Positive, Paris, 6 vols., $1830-1842$, o $4 .^{\circ}$ vol. (48." e 51." lições); o $5 .^{\circ}$ vol. e o $6 .^{\circ}$ vol. Do Système de Politique Positive...., veja-se no $3 .^{\circ}$ vol. «La Dynamique sociale ou le traité générale du progrès humain». 
historicidade à ordem fixa e a-histórica da estática social $\left({ }^{87}\right)$. Recorde-se que o projecto comtiano de ultrapassar cientificamente a "idade metafísica» implicava uma leitura sistemática da totalidade do tempo histórico. Ou, em termos mais próximos: a previsão científica do futuro da humanidade concretizada no modelo reorganizativo sociocrático só era possível a partir do domínio da lei geral do progresso histórico que A. Comte denomina lei dos três estados $\left({ }^{88}\right)$. Mas, a plena demonstração desta lei implicava a sua articulação com a história do espírito positivo, concretizada na história das ciências $\left({ }^{88}\right)$. Assim, estabelecia-se a necessidade de expôr os graus de positividade alcançados pelas ciências para mostrar como o espírito positivo atingia o grau de máxima concretude na sociologia e a partir daí, para mostrar os efeitos de optimização epistémica na tábua enciclopédica das ciências, desencadeados pela ciência comtiana.

Deste modo, o encadeamento sistemático das ciências $\left({ }^{90}\right)$. sob o triplo ponto de vista, histórico, lógico e metodológico, instituía as condições de produção da própria sociologia. Embora, paradoxalmente, esta sistematização fosse obra da física social, era esse mesmo ordenamento hierárquico das ciências que legitimava a necessidade histórica e epistemológica da última ciência. Ưltima, porque se exercia sobre todo o real ainda não cientificado, isto é. o real social que apresentava o grau de complexidade máxima e de generalidade mínima. Com efeito, segundo A. Comte, a história das ciências revela que o espírito positivo se exerceu segundo uma ordem de apropriação cognitiva do real que parte do mais simples e mais geral para o mais complexo e específico $\left({ }^{91}\right)$. A Sociologia era a última, mas também a primeira ciência porque o lugar que cada ciência ocupa na hierarquia científica é tanto mais elevado quanto mais tardia é a sua positivação, já que mais compreensivo menos extenso e mais próximo do sujeito cognoscente é o seu objecto. Daí, a posição cimeira da Sociologia. Mas se ela é a primeira e a última, é também a única

(87) A Estática social é tratada na 50." lição do Cours...., 4..$^{\circ}$ vol., e em todo o $2 .^{\circ}$ vol. do Système de Politique Positive.

(88) Veja-se a 1.a lição do Cours de Philosophie Positive; o Discurso sobre o Espirito Positivo (1844), trad. de Joel Serrão, Lisboa, Seara Nova, 1947, pp. 45-63.

(89) Veja-se a 2.a lição do Cours.

(90) Veja-se o Catecismo Positivista, pp. 64-117; em particular o quadro da «Hierarquia Teórica das Concepções Humanas, ou Quadro Sintético da Ordem Universal numa escala enciclopédica de cinco ou sete graus", p. 72 .

(91) Veja-se Cours de Philosophie Positive (1 $1^{\text {re }}$ et $2^{\text {e }}$ leçons), Paris, Larousse, 8." ed., 1946, pp. 75-87. 
porque é nela e através dela que se realiza a síntese absoluta, universal e unificadora do saber: «En effet, la fondation de la physique sociale complétant enfin le système des sciences naturelles, il devient possible et même nécessaire de résumer les diverses connaissances acquises, parvenues alors à un état fixe et homogène, pour les coordonner en les présentant comme autant de branches d'un tronc unique, au lieu de continuer à les concevoir seulement comme autant de corps isolés» $\left.{ }^{(92}\right)$. Unica, ainda, porque ela detinha a chave de toda a história temporal e espiritual da humanidade, a lei do desenvolvimento articulado do poder e do saber.

Deste modo, torna-se claro que A. Comte encerrava a inteligibilidade de todo o acontecer histórico na célebre lei dos três estados, ou seja, vazava a riqueza multifacial do processo histórico numa tórmula circular-teleológica, loga abrangente do tempo tuturo, dito último, normal e definitivo, de acordo com as previsões científicas do espírito positivo comtiano, em plena maturidade. Fundada no «dogma da invariabilidade das leis naturais» $\left({ }^{93}\right)$, a sociologia ficava autorizada a prever o futuro e incumbida de geri-lo porque a lei determinava que a história não iria continuar a desenrolar-se espontaneamente. Com efeito, a partir da positivação, também ela necessária e inevitável da Sociologia, os sábios positivistas tinham de regularizar o processo histórico ou normalizar a "marcha geral da civilização". Conforme sublinha o autor: «En résumé, science d'oú prévoyance; prévoyance d'où ac tion» $\left.{ }^{(94}\right)$. Este dado é fundamental para se avaliar o alto nível da ofensiva do cientismo sociológico. Mas importa acrescentar algo mais em função do escopo particular deste trabalho. A previsão sociológica fazia-se na base dum método específico, embora fosse tributário da metodologia das ciências físicas e biológicas. Ela não resultava de qualquer poder adivinhatório do autor, nem de alguma intuição intelectual à maneira de Descartes. Não procedia ainda dum cálculo matemático de probabilidades. Em traços gerais, o conhecimento sociológico do futuro da humanidade resultava do exercício do chamado método histórico. Este inscrevia-se na ordem de dependência hierárquica e de filiação entre os métodos das ciências estabelecidas e por isso a sua validade era inquestio-

(92) Idem, ibidem, p. 35.

(93) A. Comte, Discurso sobre o Espirito Positivo (1844)...., pp. 61-62; Veja-se também Cours de Philosophie Positive...., 4..$^{\circ}$ vol., pp. 310-327.

(94) Idem, Cours.... (1'e et 2e), p. 61. 
nável. 0 método histórico seria tão positivo como o método experimental das ciências físicas ou como a observação comparativa em que assentava a biologia. Proporcionava resultados cujo nível de cientificidade era absoluto. Para denotar esta pretensão, Comte filia-o expressamente nos processos epistemológicos da biologia, atribuindo-lhe as seguintes denominações: método de observação histórica e método de comparaçäo histórica. Querendo vincar mais ainda a legitimidade cognoscente do método histórico, Comte designa-o também de método de experimentação indirecta - expressão sintomática que o aproxima da tísica, propriamente aita. Nas, ao contrário do que o adjectivo indirecta nos poderia levar a supor, trata-se de um processo metodológico que não apenas se filia na "pura experimentação" mas ainda a desenvolve e optimiza por imperativos do objecto sociológico e mais alargadamente da própria lei dos três estados $\left({ }^{95}\right)$.

Assim, tendo presente o modelo comtiano de classificação das ciếncias, respectivos métodos e objectos, o método histórico era não só positivo como ainda superiormente positivo: era o expoente máximo do processo histórico da metodologia científica. Erguido nesta base, o saber-poder da física social não conhecia limites porque o método histórico ao estabelecer a observação comparada das etapas consecutivas da marcha civilizacional deparava a existência de verdadeiros laboratórios sociológicos: os processos revolucionários, particularmente a grande revolução francesa de 1789. Daí a atenção que A. Comte deu ao período revolucionário, "crítico», "patológico" ou "metafísico» pois, enquanto espaço laboratorial, aquele período proporcionava-lhe a prática do «experimentalismo indirecto". Na verdade, segundo o autor, tal como o caso patológico permitia à biologia exercer a "pura experimentação» também as revoluções constituíam laboratórios naturais espontâneos para experimentar hipóteses e determinar as leis reais da natureza social, estática e dinâmica, da humanidade. Textualmente: ".... j'ai démontre, en philosophie biologique, que les cas pathologiques, par suite même de leur spontanéité, constituaient, en général, le véritable équivalent scientifique de la pure expérimentation.... Or, les mêmes considerations philosophiques sont, à plus forte raison, essentiellement applicables aux études sociologiques, et y doivent conduire à des conclusions semblables, et encore mieux motivées, sur la prêpondérance nécessaire de l'analyse pathologique, comme mode indirect d'experimentation convenable à l'organisme le 342-376.

(95) A. Comte, Cours de Philosophie Positive..., 4. ${ }^{\circ}$ vol., pp. 
plus élevé et aux phénomènes les plus composés qu'on puisse concevoir» $\left({ }^{96}\right)$. Neste sentido, o método histórico, ao privilegiar o exame das perturbações da harmonia do estado social nos períodos revolucionários, decalcava o procedimento biológico relativamente ao organismo individual. Em duas palavras: o processo revolucionário estava para a sociologia como o caso patológico para a biologia; ambos equivaliam cientificamente ao experimentalismo físico. Concebido nestes termos, o método de observação histórica tornava possível o estabelecimento de ligações constantes entre os fenómenos sociais, isto é, conduzia à determinação das leis sociológicas, estáticas e dinâmicas, gerais e particulares. Daí a positividade das leis do "consenso social" ou equilíbrio harmonioso dos diversos órgãos da sociedade. Essas leis estáticas determinavam o desenvolvimento geral segundo a lei dinâmica dos três estados.

Então, se afirmámos que o "Papa positivista» vazava a historicidade na lei dos três estados, agora devemos interrogar a própria lei, expôr o dogma que a atravessa, o irredutível que lhe dá unidade e a configura de forma continuísta. E que, mesmo o estado transitório ou "metafísico», crítico e revolucionário não introduz a diferença ou a alteridade na história, mas apenas o desequilíbrio disfuncional na estrutura fixa do organismo social, à semelhança do que ocorre num qualquer corpo vivo em estado patológico.

Com efeito, A. Comte além de subordinar a dinâmica à estática social centrava esta em torno da fisiologia cerebral que, sintomaticamente, identificava com a frenologia de Gall. Este passo é decisivo para mostrar a profunda metamorfose a que a história era submetida no sistema comtiano. Em primeiro lugar, o método da comparação histórica não podia ser praticado à revelia da "teoria positiva da natureza humana», estabelecida por Comte a partir da frenologia de Gall. Neste sentido, escreve: "aucune loi de sucession sociale, indiquée même avec toute l'autorité possible, par la méthode historique, ne devra être finallement admise qu'après avoir été rationellement rattachée.... à la théorie positive de la nature humaine.... C'est dans cette exacte harmonie continue entre les conclusions directes de l'analyse historique et les notions préalables de la théorie biologique de l'homme que devra surtout consister la principale force scientifique des démonstrations sociologiques» $\left({ }^{97}\right)$. Não se tratava, portanto, de

(96) Idem, ibidem, p. 344 (sublinhado nosso).

(97) Iátem, ibidem, p. 373. Vejam-se do Cours...., 4. vol., a 40.", 45." e 49.气 lições. Ou no Catecismo Positivista, ob. cit., pp. 106-117, 
introduzir na história uma natureza humana de tipo metafísico mas uma "teoria biológica do homem» ou "teoria sistemática do cérebro e da alma" de inspiração fisicalista. Abreviemos: o significado da obediência do método histórico aos dezoito órgãos cerebrais, comandados pelos dez motores da região afectiva (sete egoístas e três altruístas), é claro: trata-se da subordinação da história a uma geometria frenológica da espécie humana. Por isso, a primeira norma da divisa positivista, deduzida da experimentação indirecta dos fenómenos sociais, é o amor. Daí também a previsão sociológica do futuro altruísta da Humanidade, fundado na bossa da bondade ou amor universal (simpatia); daí o cuidado que Comte colocou no estabelecimento da religião da Humanidade, etc., etc.

Poderia a história renovar-se, aceitando como instância determinante do processo histórico a ordem ou desordem dos sentimentos, ainda que por detrás dos jogos afectivos se erguesse a voz autorizada da biologia? Não nos parece. As historiografias que recusam o antropologismo, evitam cair neste perigo epistémico. Nem a fisiologia cerebral oitocentista à maneira de Gall, nem as actuais etologias de $\mathrm{K}$. Lorenz e de $\mathrm{N}$. Tinbergen, inspiradas na gramática darwiniana das emoções, nem as sociobiologias de E. Wilson e de W. O. Hamilton $\left({ }^{98}\right)$, nenhuma destas disciplinas poderá ditar-lhes a verdade última da história. $\mathrm{O}$ que $\mathrm{A}$. Comte oferecia à história era, justamente, aquilo de que ela não carecia: uma teoria positiva da natureza humana que funcionava enquanto controlo apriorístico do método histórico e que garantia prever o futuro a partir da previsão do passado $\left({ }^{99}\right)$. Assim, o cientismo sociológico escoava-se num antropologismo porque a própria lei dos três estados ficava vazada numa natureza humana, mecanicamente mais egoísta do que altruísta (sete motores egoístas e três altruístas). No fundo, os três estados históricos são um só e mesmo estado que, exposto ao tempo, se desenvolveu, à semelhança de um corpo vivo. Com esta diferença agravante: o organismo individual está sujeito ao meio exter-

particularmente a "teoria sistemática do cérebro e da alma» esquematizada na "Classificação Positivista das Dezoito Funções Interiores do Cérebro", pp. 110-111.

(98) Veja-se António Bracinha Vieira, Etologia e Ciências Humanas, Lisboa, Imprensa Nacional, 1983, pp. 7-125.

(99) A. Comte, Cours..., 4..$^{\circ}$ vol., p. 368. 
no, enquanto o corpo histórico não tem exterior. Nenhuma providência ou acaso pode sobressaltar a história; nenhum livre arbítrio a pode manipular ou modificar. A própria fase crítica do período revolucionário-metafísico é necessária e "positiva» como as ilusões juvenis que preparam a adultez «normal», hígida e estável.

Eis, pois, sumariamente um resultado exemplar da aplicação do modelo de racionalidade hipotético-dedutivo, próprio das ciências exactas, aos fenómenos histórico-sociais: a redução do processo histórico à "invariabilidade das leis naturais" isto é à lei dos três estados afectivos da natureza humana. Esta é concebida como sendo um absoluto a-histórico materializado numa geografia cerebral imutável que aspira a um funcionamento equilibrado e harmonioso isto é, ao estado normal e positivo.

Por isso, a historicidade em Comte não comporta as nocões de mudança, ruptura, inovação, menos ainda de imprevisibilidade, acaso ou devir indeterminado. Então impõe-se perguntar: não será paradoxal conceber uma história na qual a história não existe pois o novo é sempre a mesmidade invariável? $\mathrm{O}$ olhar sociológico através do método histórico provou a unidade continuísta da "marcha geral da civilização». Mas, em última análise, é a crença no fixismo da espécie humana e o dogma da eterna natureza humana (já não metafísica, mas estritamente física-frenológica), que, em sintonia perfeita, sustentam a prática científica comtiana. No fundo, "sa vision du monde demeure imprégnée d'une sorte de rigidité polytechnicienne» $\left({ }^{100}\right)$, ou dizendo de outro modo: é o pensamento sub specie machinae que governa a ciência una, unificadora, total, definitiva e única: a física social. E se a história é, por um lado, o objecto da sociologia e por outro lado, como se viu, o seu método, o caminho, ou melhor, o seu campo laboratorial, se ela toma "nécessairement l'histoire pour principale base scientifique» $\left({ }^{101}\right)$, que estatuto é reservado para a historiografia? Sabe-se que a História não consta na tábua enciclopédica das ciências, porque, obviamente, ela não é considerada ciência e está destinada a deixar de ser ela própria $\left({ }^{102}\right)$, a perder a sua autonomia. Assim se compreende

p. 371 .

${ }^{(100)}$ Georges Gusdorf, Introduction aux sciences humaines.....

(101) A. Comte, Cours...., 4..$^{\circ}$ vol. p. 466 (sublinhado nosso).

(102) Cf. Idem, ibidem, pp. 365-366. 
a crítica comtiana à historiografia do seu tempo $\left({ }^{103}\right)$, o seu propósito de disciplinar os estudos históricos, de os integrar na sociologia enquanto unidade científica autónoma. Com efeito, para além desta, mas não distinta dela, Comte apenas reserva um lugar na tábua enciclopédica das ciências. Esse espaço é ocupado pela Antropologia ou Moral o que vem reforçar o valor da teoria positiva da natureza humana na economia cientista do autor. Por outro lado, na sistemática comtiana a história não pode ser uma disciplina à parte (como acontece, por exemplo, no triedro dos saberes de M. Foucault) porque a filosofia positivista não tolera a excepção, nada coloca fora de jogo.

Uma vez que, segundo A. Comte, a historiografia continuava a dar expressão ao espírito teológico e ao espírito metafísico, cultivando o literário e o descritivo, e porque o sistema comtiano não admitia dois discursos paralelos e diferentes sobre o mesmo objecto, tornava-se necessário positivar a história, "préparer sa rénovation finale...., en établissant enfin une vraie filiation rationelle dans la suite des événements sociaux, de manière à permettre, comme pour tout autre ordre de phénomènes, et entre les limites générales imposées par une complication supérieure, une certaine prévision systématique de leur succession ultérieure" $\left({ }^{104}\right)$. Deste modo, Comte, ao instituir o método histórico, fundava a cientificação da história exactamente de acordo com o modelo físico, hipotético-dedutivo. Melhor: fazia coincidir a ciência histórica assim concebida com a sua sociologia ou ciência política. Não era a História, enquanto ciência, que estabelecia a filiação racional no curso dos acontecimentos, mas a física social. Era esta que ao prever o passado podia prever o futuro.

Curiosamente, a síntese sociológica ao instituir a religião da Humanidade sacralizava a própria história. Mas isto mesmo, traduzia-se desde logo, na imposição de limites à historiografia porque transformando a história num objecto de culto, numa sociolatria ao serviço da sociocracia, ela não podia ser reescrita e portanto deixava de ser histórica. Em suma, Comte desistoricizava a história.

Apesar da intencionalidade científica-normativa-objectiva (sociologia-sociolatria-sociocracia) do sistema comtiano se

(103) Idem, ibidem, pp. 362-376. Veja-se em particular a ilustra ção comtiana do "....danger de la méthode des séries historiques» (sublinhado nosso), pp. 371-372.

(104) Idem, ibidem, p. 225. 
fundar na história, apesar do culto do Grande ser, apesar ainda dos sessenta volumes de História que constam na «Biblioteca Positivista» $\left({ }^{105}\right)$, apesar do "calendário positivista», histórico mas sacrossanto, apesar de tudo isto, ou melhor, por causa disto mesmo, o olhar do historiador era maquinizado e subjugado à visão panóptica da sociologia. Esta não pretendia devolver à história algo que pudesse ser tomado como equivalente do contributo que dela recebera. Em vez desta relação interdisciplinar, a sociologia assumia-se como o saber-poder hierático mediante o santo sacrifício da história.

Fica assim exposto, de forma abreviada, o profundo desequilíbrio que esta jovem ciência provocava no quadro geral do saber oitocentista, ele mesmo tendencialmente hierófobo, como o prova alegoricamente tudo o que está envolvido na metáfora da morte de Deus. Em termos simples: uma sociedade aberta e móvel não poderia identificar-se com um sistema fechado e sagrado. O cientismo comtiano é, todavia irredutível a uma hieromania inconsequente $\left({ }^{108}\right)$, apesar do industrialismo moderno não poder, estruturalmente, sintonizar-se com as utopias oitocentistas do retorno ao consensus harmonioso como in illo tempore...

Talvez não seja possível fazer história sem amar a própria história como diz Lucien Febvre $\left({ }^{107}\right)$; mas amá-la ao ponto de a desistoricizar, deificando-a, é algo que a historiografia positivista-metódica não podia aceitar. Daí o seu empenho em fazer história sem apriorismos, sem teorias da natureza humana, positivas ou outras, sem lei dos três estados ou outras leis - daí a contra-ofensiva duma estratégia historiográfica fundada basicamente na análise exegética e na crítica filológica dos documentos escritos. Julgava-se que este procedimento metodológico indutivo, conduzido com rigor, tornaria possível uma síntese a posteriori tão válida e científica como os resultados da investigação física e química. Mas essa síntese final impunha a análise prévia e completa de toda a documentação atinente a um determinado quadro geo-histórico porque o positivismo historiográfico recusava a actividade selectiva das fontes. Neste sentido, é por demais conhecida a afirmação

(105) Veja-se «Bibliothèque Positiviste au dix-neuvième siècle» in Système de Politique Positive ou Traité de Sociologie instituant la Religion de l'Humanité, vol. IV, Paris, Mathias, 1854. «Appendice».

(106) Cf. Amadeu Carvalho Homem, Algumas notas sobre 0 positivismo religioso e social», separata da Revista de História das Ićeias, vol. 9, Coimbra, 1987.

${ }^{(107)}$ Lucien Febvre. Combates pela História, Lisboa, Editorial Presença, 2." ed., 1985, pp. 28-41. 
de Fustel de Coulanges, segundo a qual "pour un jour de synthèse, il faut des années d'analyse» $\left({ }^{108}\right)$. Embora estas exigências metodológicas tenham tornado a feitura da história mais morosa e mesmo nalguns casos inviável, como confessa Ch. Seignobos $\left({ }^{109}\right)$, o importante é que elas testemunham, desde logo, a demarcação da historiografia positivista do cientismo comtiano. Por isso, deve sublinhar-se que o historiador metódico "fasciné par la gloire d'un Berthelot» (110) ao renovar a historiografia mediante o exercício do espírito analítico-filológico acusava a falta de rigor e de consciência das leis comtianas legitimadas pelo seu "método histórico», denunciava a idade da sociologia, ou melhor, a sua menoridade. Em suma: estancava a pretensão sociológica à inteligibilidade universal da história.

Tratava-se, sem dúvida, dum renascimento historiográfico sério, parafraseando Huizinga $\left({ }^{111}\right)$, do abandono do lúdico que tinha caracterizado o romantismo. E o sério em história, como noutras áreas do saber, significava a procura obsessiva da sua cientificação tendo como referente as ciências exactas. E no horizonte deste modelo que Fustel de Coulanges pensa a natureza da história: "Elle n'est pas un art, elle est une science pure.... Elle consiste comme toute science, à constater des faits, à les analyser, à les rapprocher, à en marquer le lien»; o historiador realizará este ideal científico não tendo "d'autre ambition que de bien voir les faits et de les comprendre avec exactitude. Ce n'est pas dans son imagination ou dans sa logique qu'il les cherche; il les cherche et les atteint par l'observation minutieuse des textes, comme le chimiste trouve les siens dans des expériences minutieusement canduites» $\left({ }^{112}\right)$. Cultivando o factualismo e perseguindo o tempo aberto, feito de empiricidades, tendendo mais para o individualizante do que para o generalizante. a história logrou equilibrar o quadro epistémico da modernidade.

No actual contexto epistémico a história pode assumir e tem assumido posições metodológicas diferentes e críticas

(108) Fustel de Coulanges, Histoire des Institutions politiques de l'ancienne France, cit. por Georges Gusdorf, Introduction aux sciences humaines...., p. 417.

(109) Veja-se Charles Seignobos, Histoire politique de l'Europe contemporaine, Paris, A. Colin, $7{ }^{\circ}$ éd., 1924, T. I, pp. V-VI.

(110) Georges Gusdorf, ob. cit., p. 417.

(111) Veja-se J. Huizinga, Homo ludens. Essai sur la fonction sociale $d u$ jeu, traduit du néerlandais par Cécile Seresia, Paris, Gallimard, 1977, p. 308. nosso).

(112) Citado por Georges Gusdorf, ob. cit., p. 417 (sublinhado 
relativamente ao modelo positivista, cuja soberania se julga, por vezes, precipitadamente, ter declinado a partir da revolução dos Annales. Todavia, hoje, seria oportuno que o discurso do método por vir mostrasse desapaixonadamente as qualidades a vários níveis e também as limitações do ideal positivista da escrita da história face à complexidade actual das condições de produção do saber histórico.

Aqui, tratou-se apenas de mostrar que o historiador metódico-positivista soube responder às necessidades da história, afirmar a sua autonomia, a extensão do seu campo e o seu valor num quadro epistémico que foi palco de modificações e inovações tão profundas como aquelas que, entretanto, eram vividas pelas sociedades abertas à dinâmica capitalista liberal ou demoliberal - salvaguardando as suas diferenças e excluíndo quer a causalidade mecânica, idealista ou materialista, quer o paralelismo especulativo entre zonas do real que têm ritmos organizacionais distintos.

Em suma: o historiador positivista à maneira de Fustel de Coulanges, de Langlois ou Seignobos, não se eximiu da séria responsabilidade de travar o perigo do sociologismo no quadro geral do saber moderno. Não foi este, todavia, o único modo como assumiu a sua actualidade. Ele não combateu apenas a irrupção do a-historismo no plano do saber e do acontecer, provocado pela jovem sociologia; ele não lutou apenas contra a morte da historiografia e da história anunciada de forma tão séria e elegante quanto paradoxal pela escrita comtiana. Ele enfrentou também a desistorização das sociedades ocidentais produzida pelas novas condições materiais e espirituais de existência social, historiando a morte de Deus, ou melhor, a decomposição da vontade divina patente nas aflições do trono e do altar. E assumiu ainda a sua actualidade lutando contra o excesso de história jorrada desordenadamente pela energia agressiva, dinâmica e desenvolvimentista das potências ocidentais desde meados do séc. XIX. Com efeito, a história positivista construiu também a memória, sobretudo política, dos povos; moldou o corpo das nações que procuravam a sua própria identidade com uma ânsia calculada e não menos séria vontade de poder. Por tudo isto se julga que a história, hoje, não pode recusar a questão da sua actualidade e não pode pensá-la sem rever a estratégia que a historiografia positivista inaugurou. Esta deve ser tomada como um referente diurno, vivo e actual pois, como escreve Luís Reis Torgal "o alargamento dos temas de estudo, dos aparelhos conceptuais, das estratégias metodológicas, da utilização de instrumentos de análise, não pode dar-nos a 
sensação que o 'novo mundo epistemológico' descoberto deve subalternizar o 'velho mundo' das análises historiográficas...." (113). Apesar dos novos e diversificados valores que a escrita da história tem perfilhado, sobretudo desde a década de cinquenta, é inegável que ela continua atraída pelo modelo de cientificidade das disciplinas exactas. Com efeito, uma parte significativa do seu esforço orienta-se para o estabelecimento de leis, regularidades e tendências sendo justamente neste horizonte que ela tem procurado resolver o grande problema de Charles Seignobos, a saber "l'abondance écrasante des documents" $\left({ }^{114}\right)$. O caminho percorrido desde a revolução positivista mostra bem que o ideal de optimizar esta metodologia tem sido uma constante historiográfica. Os seus princípios, desde a crítica interna dos textos à valorização da cronologia, consideram-se, hoje, aquisições definitivas para as ciênzias historiográficas. Também. como vimos, relativamente ao problema da actualidade da história, a lição positivista está cheia de ensinamentos. Por isso, parece-nos oportuno que a história, hoje, ao pensar a sua relação com o tempo presente, o modo como se inscreve nele, o assume e interpreta, releia com "o máximo de consciência possível» a defesa positivista-metódica da história. Os tempos mudaram e os combates são outros, mas a estratégia das ciências humanas reforçou-se e os cientismos multiplicaram-se. A episteme moderna, actualmente em crise, ainda se deixa reconhecer, tanto mais quanto é certo que o antropologismo está de regresso e o comtismo ganha cada vez mais actualidade.

Conclusão: Políticas da historiografia, um problema historiosófico

Presentemente, a história parece cansada do tempo linear, quantitativo, horizontal, do tempo extensivo, da longa duração serial, numa palavra, de Chronos sem Kairos. Pelo menos, como escreve Michel Vovelle, "nous assistons aujourd'hui au retour de l'événement, au sortir d'une 'longue durée' qui pourrait sembler hier sur le point de se figer dans 'l'histoire im-

(113) Luís Reis Torgal, «História.... Que História? Algumas reflexões introdutórias à temática da história local e regional», Revista de História das Ideias, n. ${ }^{\circ}$ 9, Coimbra. 1987, p. 861.

(114) Charles Seignobos, ibidem. 
mobile'» $\left.{ }^{115}\right)$. E o mais curioso é que este retorno ao acontecimento, segundo a expressão já consagrada de Pierre Nora, verifica-se também "chez les historiens les plus attachés à l'analyse des structures et des phénomènes de longue durée» $\left.{ }^{118}\right)$. O que se passa, então? "Phénomène de mode, retour du balancier? Elément d'un compromis historique où les longues plages d'immobilité d'une anthropologie parfois à peine historique céderaient la place hier, ou même aujourd'hui, à la frénésie d'un mouvement brownien, événementiel?» ${ }^{117}$ ) - pergunta Michel Vovelle. Os grandes historiadores dão respostas interrogativas, o que prova que ainda é cedo para inteligir os sentidos do actual interesse historiográfico pelas singularidades acontecimentais.

E verdade que nas últimas décadas se recalcou o grandioso enunciado de Seignobos, segundo o qual «l'histoire, c'est la science des choses qui n'arrivent qu'une fois" ( $\left.{ }^{118}\right)$. Será que o regresso do acontecimento, volte a dar sentido a esta fórmula que, a nosso ver, não é necessariamente paradoxal! Por outro lado, não é igualmente certo que a era da formalização dos estudos históricos está aí! Haverá nesta tensão historiográfica quaisquer equívocos? Se a história é "virtuellement événementielle et virtuellement structurale» $\left.{ }^{119}\right)$ como diz Paul Ricoeur, porque não supor que os estudos históricos atravessam uma fase de desenvolvimento que aponta no sentido de possibilitar a conjugação de Chromos com Kairos? De qualquer modo, a valorização das «coisas que só acontecem uma vez» não significará que a escrita da história não pode identificar-se totalmente com «a univocidade e a isotopia do ideal científico" $\left({ }^{120}\right)$ ? Com efeito, a filosofia ensina-nos que "a ciência elimina a conotação e o nível secundário da significação e, através da construção de uma linguagem artificial, atinge o rigor e a exactidão do discurso meramente designativo e informativo" $\left.{ }^{121}\right)$. Não é certamente o

(115) Michel Vovelle, in L'événement (Actes du Colloque organisé à Aix-En-Provence par le Centre Meridional d'Histoire Sociale les 16, 17 et 18 Septembre, 1983), Publications Université de Provence, 1986, p. 332 .

(116) Philippe Joutard in L'événement...., p. 1.

(117) Michel Vovelle, ibidem.

(118) Citado por Georges Lefebvre, La naissance de l'historiographie moderne...., p. 323.

p. 79.

(119) Paul Ricoeur, Histoire et Vérité, Paris, Seuil, 3. ed., 1964,

(120) Miguel Baptista Pereira, «Experiência e sentido», Biblos, Coimbra, vol. IV, 1979 , p. 358.

(121) Idem, ibidem. 
caso da história, nem nos parece que ela procure aproximar-se deste ideal. Pois, se assim fosse, ela ter-se-ia desembaraçado das singularidades, contrariamente ao que está ocorrendo. Mas se é este o caminho que algumas historiografias querem trilhar, então deve acrescentar-se que, actualmente, ele não satisfaz as ciências naturais. Estas pretendem ultrapassar o sentido funcional, unívoco e técnico e para isso ensaiam um diálogo com os estudos humanísticos mediado pelas ciências sociais. O modelo de conhecimento sub specie machinae está em crise e a julgar pelas palavras rigorosas de Boaventura de Sousa Santos, "não virá longe o dia em que a física das partículas nos fale do jogo entre as partículas, ou a biologia nos fale do teatro molecular ou a astrofísica do texto celestial, ou ainda a química da biografia das reacções químicas» $\left({ }^{122}\right)$. Acrescentando este quadro à própria natureza da história, nos termos em que Paul Ricoeur a define, parece-nos legítimo concluir que os estudos históricos não podem recusar o modelo de inteligibilidade compreensiva do acontecer; não podem cultivar exclusivamente o modelo manipulatório $e$ normalizador do real histórico que reprime a alteridade $e$ a diferença e instrumentaliza o corpo da história. De resto, o contrário só seria possível se a história estivesse realmente preparada para se transformar numa engenharia do acontecer que planificasse e tecnizasse o tempo segundo uma lógica funcional, reeditando a obsessão comtiana de prever-programar o futuro, a partir da previsão do passado. Todavia, alguns historiadores acreditam, ou melhor, ainda estão interessados na cientificação unívoca da história, na classificação homogeneizadora do acontecer, na extinção dos sentimentos do sujeito que a constrói. Julga-se que, deste modo, a história conquista um nível de cientificidade que a torna imune aos problemas do quadro epistémico-político em que se inscreve? Admitir-se-á que, sem opiniões, sem perspectivas, sem juízos de valor e sem afectos, a história se emancipa das ideologias, convertendo-se num vasto campo neutro onde é suposto que uma verdade incolor se expõe ao olhar geométrico do estudioso? E porque é que este ideal historiográfico tem para alguns historiadores um elevado valor pedagógico, enquanto outros dispensam o potencial normalizador desta história e interpretam-na numa óptica estritamente lúdica-contemplativa?

(122) Boaventura de Sousa Santos, Um Discurso sobre as ciências...., p. 45 . 
Vejamos o problema: na nossa perspectiva a neutralidade da história "geométral» é apenas aparente porque toda a história tem uma face político-cultural como quaisquer outras disciplinas, sejam as duras, isto é, as exactas, sejam as poéticas, as lúdicas, as técnicas ou as religiosas. A história não é (não foi, nem poderá ser) um discurso expositor-espectador do acontecer pretérito e presente, mesmo que acalente essa vontade. Também não é um divertimento privado ou público. Não subestimamos a memória histórica como Paul Veyne ao afirmar, talvez com um clarividente realismo, que "l'histoire est un des produits les plus inoffensifs qu'ait jamais élaborés la chimie de l'intellect» $\left.{ }^{123}\right)$. Pelo contrário, a memória e o imaginário históricos são entidades talvez tão operativas como os códigos jurídicos na economia política da vida social. Todavia, esta questão tem uma complexidade sui generis porque põe em jogo a relação entre "a memória histórica matriz e as memórias históricas sociais» $\left({ }^{124}\right)$, o que significa que ela tem de ser tratada no âmbito das relações entre História e Ideologia, como o prova, em concreto, a obra, recém-publicada, de Luís Reis Torgal. Neste sentido, o autor explorou uma série de indicadores para determinar o valor social da história: «a historiografia, as bibliotecas, os manuais e os programas escolares, a literatura histórica infanto-juvenil». Mas acrescenta: "Importa, todavia, estar atento a muitos outros: o teatro, a canção e outros tipos de manifestações artísticas, as estátuas e outros monumentos evocativos, a toponímia urbana, o movimento editorial, etc., etc. Estamos num campo aberto em termos de objecto de estudo - e não devemos ter receio de utilizar material que à partida poderá parecer 'pouco digno' da investigação histórica - como de

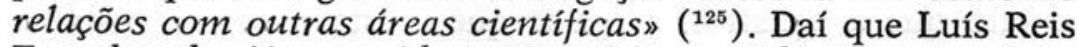
Torgal tenha já recorrido ao inquérito sociológico para obter um tipo de informação que, relacionada com as demais, permita objectivar "a memória histórica social» gerada pelas "memórias históricas matrizes». $\mathrm{Na}$ verdade, este trabalho não só contribui valiosamente para pôr termo à ilusão de neutralidade político-cultural da historiografia de ontem e de hoje, mas ainda procura focar a problema na sua pluridimensionalidade. $O$ que a obra desde logo nos ensina é que o problema em causa, certamente um dos mais sensíveis para

(123) Paul Veyne, Comment on écrit l'histoire...., p. 63.

(124) Luís Reis Torgal, História e Ideologia, Coimbra, Minerva, 1989 , p. 249 (sublinhado nosso).

(125) Idem, ibidem, p. 250 (sublinhado nosso). 
o historiador, não pode ser abordado em termos pragmático-funcionalistas porque esta visão redutora não daria conta nem da diversidade de factores a que é necessário atender, nem dos variados modos de ser (sincrónicos e diacrónicos) da história, das suas múltiplas e heterogéneas maneiras de estar no quadro geral do saber, no imaginário social (académico, artístico, político, militar e outros) ou na cultura.

Igualmente se compreende, a partir de História e Ideologia, que não é possível encerrar um tão vasto e permeável problema numa perspectiva ético-normativa. Neste ponto, Hegel tinha alguma razão ao denunciar as ilusões dos historiadores que julgavam extrair do passado ensinamentos para o presente. Nas suas Lições sobre a filosofia da história, lê-se: "O que a experiência e a História nos ensinam, é que os povos e os governos nunca aprenderam nada com a história e nunca actuaram de acordo com as máximas que dela se teria retirado. Cada época tem as suas condições particulares, constitui uma situação tão individualizada que só é possível decidir em função dela. No tumulto dos problemas do mundo, uma máxima geral serve tanto como a recordação de situações análogas, porque uma coisa, tornada uma simples recordação, não tem força diante da vida e da liberdade do presente» $\left.{ }^{126}\right)$. Na verdade, a historiografia não é, nem pode ser a consciência normativa e preventiva da iniludível imprevisibilidade da história. Contudo, a ciência histórica tem responsabilidades culturais e é no modo como as assume que perpassa a dimensão política do seu valor social. Mesmo numa sociedade demoliberal-tecnocrata a história, enquanto disciplina ensinada e divulgada, contribui para estruturar sentimentos diversos de pertença a um todo; para religar inconscientemente as gerações entre si na ordem diacrónica e sincrónica; para construir o imaginário social particular ou geral; para moldar o reconhecimento do poder do passado sobre o presente mas também do presente sobre o passado e o futuro. Estes dados não se podem recusar.

Com efeito, é por ter consciência das suas responsabilidades que a história não recalca a necessidade de se auto-interrogar, não expulsa do seu horizonte os problemas gnosiológicos que se lhe deparam, nem se limita a sofrê-los à maneira dum Montaigne. E por isso que ela teve necessidade de desenvolver uma teoria da história intimamente relacionada

(126) Citado por François Châtelet. O Pensamento de Hegel, Lisboa, Ed. Presença, 1976, p. 213 (sublinhado nosso). 
com o trabalho historiográfico a partir da revolução positivista. E igualmente porque se assume como ciência responsável pelos seus métodos, linguagens, resultados e efeitos político-culturais que a história não se aliena das questões que são suas, questões muitas vezes «inteiramente filosóficas" ${ }^{127}$ ), como diz Roger Chartier. No mesmo sentido, é particularmente sintomático que a história, hoje, procure estabelecer um diáloga aberto com a filosofia - o que, desde logo, contraria a sua actual tendência cientista.

Importa que nos detenhamos neste ponto. Não é possível, no espaço deste artigo, mesmo em traços largos, precisar a multiplicidade de relações que a história manteve com a filosofia desde a revolução metodológica positivista. Mas diga-se que, até hoje, o relacionamento do espírito histórico com o espírito filosófico não foi homogéneo e constante na medida em que atravessou fases, muitas vezes simultâneas, de cumplicidade, indiferença, antagonismo, desconfiança, confusão e outras. Não se pode dizer que, genericamente, tenha sido uma relação negativa ou que tenha funcionado como um travão epistemológico para as ciências historiográficas pois, nalguns casos, ela desencadeou a eclosão de conflitos no interior da história o que, só por si, é radicalmente positivo. Contudo, a forma de relacionamento que actualmente se prefigura é algo de novo nesta matéria: trata-se do diálogo activo, isto é, de um estilo de comunicação interdisciplinar que se propõe salvaguardar a autonomia soberana quer da história, quer da filosofia. Esta relação dialogante é, sem dúvida, particularmente exigente, pois para ser fecunda o historiador não pode fazer do presente um tabu, o filósofo não pode ser insensível às positividades cronológicas da história, devendo ainda, ambos, não confundir Historie e Geschichte. Ora, desde a década de cinquenta têm-se reunido condições internas e externas para viabilizar este "convívio necessário e proveitoso» $\left({ }^{128}\right)$. Ele é, hoje, possível, basicamente porque a historiografia, em particular a história das ideias, a história das ciências e a história tout court "que trabalha com descontinuidades, desfasamentos, diferenças" ( ${ }^{129}$ ) fundou um modelo de inteligibilidade do acontecer histórico que ultrapassa o hegelianismo. Recorde-se que diversos autores mostraram a distância que separa a história nova da referência hegeliana. Para Jacques Le

\footnotetext{
(127) Roger Chartier, A História Cultural entre práticas e representações, Lisboa, Difel, 1988, p. 69.

(128) Idem, ibidem, p. 89.

(129) Idem, ibidem, p. 74.
} 
Goff $\left({ }^{130}\right)$, mas também segundo Roger Chartier $\left({ }^{131}\right)$, foi Foucault, considerado "um dos maiores historiadores novos", quem «fez o diagnóstico mais perspicaz sobre esta renovação da história» ( ${ }^{132}$ ) na sua Arqueologia do saber, em $A$ ordem do discurso e noutros textos mais recentes. Importa-nos aqui sublinhar, apenas, que a história nova alicerçando-se num conjunto de métodos novos, num novo estatuto do documento-monumento ergueu, contra o espírito hegeliano, a noção fulcral de descontinuidade. "Un des traits les plus essentiels de l'histoire nouvelle, c'est sans doute ce déplacement du discontinu.... il ne joue plus le rôle d'une fatalité extérieure qu'il faut réduire, mais d'un concept opératoire qu'on utilise; et par là l'inversion des signes grâces à laquelle il n'est plus le négatif de la lecture historique (son envers, son échec, la limite de son pouvoir) mais l'élément positif qui détermine son objet et valide son analyse» $\left({ }^{133}\right)$. Deste modo, o valor que a história nova atribui ao descontinuismo traduz expressamente a sua impossibilidade de se harmonizar com Hegel. Por outro lado, a filosofia não ficou paralisada pela tirania do logos hegeliano mas espraiou-se por novos e variados caminhos, manteve-se atenta à multiplicação dos saberes-poderes, procurou as interrogações autênticas do seu tempo. Em suma: renasceu, pois era impossível romper o círculo do saber absoluto $\left.{ }^{134}\right)$. $\mathrm{O}$ que tudo isto significa é que o logos avassalador já não pode perturbar a relação da História com a Filosofia. Na verdade, a noção idealista de totalidade necessária e teleológica instituída por Hegel perdeu o seu valor de uso, mas também o seu poder lógico-explicativo. $\mathrm{O}$ mesmo destino teve o princípio da continuidade fundado num espírito absoluto, uno e omnipresente, auto-realizando-se segundo uma lógica dialéctica em todos os domínios da vida. A historiografia nada tem a recear duma razão que mostrava o seu poder identificando-se com a própria história e visando teleologicamente a auto-consciência do espírito. a sua auto-realização e libertação final. Ao dialogar com a filosofia, a história

(130) Jacques Le Goff, "História», in Enciclopédia Einaudi...., pp. 216-218.

(131) Veja-se Roger Chartier, ob. cit., pp. $69-89$ e em particular o ponto 3 intitulado "Renunciar a Hegel» no qual af:rma que sobre este problema "a constatação mais penetrante é incontestavelmente a apresentada por Michel Foucault em todo um conjunto de textos de finais dos anos 60 ", p. 74.

(132) Jacques Le Goff, "art. cit.», p. 216.

(133) Michel Foucault, L'archéologie du savoir, Paris, Gallimard, 1969, p. 17 (sublinhado nosso).

(i34) Veja-se François Châtelet, ob. cit., pp. 231-253. 
já não corre o risco de ser reduzida a uma mecânica espiritualista que, dialecticamente, de volkgeist em volkgeist alcançaria a plenitude do weltgeist. Vejamos o que diz a escrita hegeliana amenizada pela língua francesa: "L'esprit qui pense l'histoire du monde, après s'être dégagé de ces bornes des esprits nationaux particuliers et de l'emprise du monde qui lui est propre, appréhende son universalité concrète et s'éléve à la connaissance de l'esprit absolu, la vérité éternellement réelle en laquelle la raison qui sait, est libre pour soi tandis que la nécessité la nature et l'histoire ne sont que les instruments de la révélation de l'Esprit et les vases d'élection de sa gloire» $\left({ }^{135}\right)$. Este discurso totalitário que faz da história um «instrumento» do espírito absoluto (redução integradora) já não oferece resistência ao caleidoscopismo historiográfico dum Paul Veyne ou à soberania do descontínuo e da distinção proclamada pela história nova. Esta, em lugar de reduções, opera distinções; em vez de fazer da razão a única e legítima instância legisladora, o trabalho historiográfico não apresenta princípios, normas ou regras sem auscultar pacientemente os «factos», as provas, os documentos. Tem como regra de ouro não impôr a identidade onde lê diferenças, desfasamentos, incomensurabilidades.

Poder-se-ia dizer que a cadeia de enunciados sistemáticos de Hegel não colhe provas que a sustentem. Por exemplo, a tese segundo a qual cada época histórica é dominada pela supremacia dum espírito nacional. Que provas autorizam este enunciado? Qual a sua natureza? Que «factos»? Mas, a filosofia hegeliana é surda aos argumentos historiográficos. Eles nada adiantariam porque o diáloga com Hegel é impossível, o seu sistema é perfeito e não faz sentido interrogá-lo neste ou naquele domínio particular. Como concluiu François Châtelet «.... o seu sistema em si é irrefutável... não é refutá-lo fazer referência a 'factos' (que factos do domínio da história das ciências, das culturas, dos povos, da História pura e simplesmente, podem valer contra uma teoria - contra uma ordem fundamentada do discurso - que estabelece, precisamente, o que há a estabelecer como 'facto'»? $\left.{ }^{136}\right)$. E depois, se tudo se equivale, a relação da história com o hegelianismo só podia saldar-se numa absurdidade. «O Absoluto é Sujeito,

(135) Hegel, Précis de l'Encyclopédie des sciences philosophiques, trad. J. Gibelin, Paris, J. Vrin, 1952, pp. 293-294.

(136) François Châtelet, ob. cit., p. 232. 
o Ser é Razão, o Pensamento é Discurso" $\left({ }^{137}\right)$; a História é a história da Razão que é Real e do Real que é Razão.... Que entendimento construtivo era possível entre historiografia e filosofia da história hegeliana, entre Historie e Geschichte, se "o hegelianismo admite, como facto de razão, por isso evidente, que todas as linguagens são homogéneas umas às outras e que o lugar da sua homogeneidade é o lugar da sua integração" $\left({ }^{138}\right)$ ! A historiografia, simplesmente, renunciou a Hegel, para retomar a expressão de Paul Ricoeur que serve de título às reflexões de Roger Chartier. Vendo bem, a história pode prescindir, sem sacrifício, do optimismo cósmico da filosofia hegeliana. Afinal, que trunfos colheria se aceitasse o impiedoso princípio da necessidade lógica do progresso da consciência da liberdade através do qual, segundo Hegel, o espírito desenvolve a sua auto-consciência até se apreender na sua universalidade concreta? Ou em termos mais simples: que avanço historiográfico seria facultado pela afirmação de que "os orientais chegaram ao conhecimento de que um só é livre, os Gregos e os Romanos tinham consciência de que alguns eram livres, mas nós sabemos que todos os homens, em si, são livres....» $\left({ }^{139}\right)$. De que serve ao historiador o conhecimento - reconhecimento da liberdade de todos os homens enquanto princípio do "fim da história», isto é, enquanto início do devir transparente da humanidade no estado mundial! Que efeitos científicos podia desencadear a teodiceia hegeliana na produção historiográfica? Questões inúteis, todas elas, porque, ou se aceita entrar no jogo do hegelianismo (e então não há nada para perguntar dado que, nele, todas as coisas têm o seu lugar e tudo é real e verdadeiro), ou se renuncia ao sistema na sua totalidade. Não é possível retomar este ou aquele princípio de Hegel sem cair na roda dentada do saber absoluto, como aconteceu a Marx, a Croce, a Antero de Quental e a outros, todos eles, no entanto, profundamente originais.

Mas, a história nova, ao menos a história das ideias, das ciências, e a história tout court, que objectiva descontinuidades, diferenças, rupturas, limiares, séries e incomensurabilidades, essa abandonou Hegel e pacientemente construiu a segurança que agora manifesta. Ela tem consciência de que as

(137) Idem, ibidem, p. 243.

(138) İiem, ibidem, p. 247.

(139) Hegel, Lições sobre a filosofia da história, cit. por F. Châtelet, ob. cit., p. 215. 
suas questões historiológicas, historiométricas e outras são problemas que devem ser colocados «na fronteira da prática historiográfica e da reflexão filosófica» $\left({ }^{i 40}\right)$, só podendo ser resolvidos pelo diálogo da história com a filosofia - ambas desembaraçadas do logos hegeliano.

Assim, se é verdade que a história, hoje, pede lições à física e à antropologia, não é menos certo que ela está a investir num relacionamento interdisciplinar ou talvez desdisciplinar com a filosofia. Então, isto significa que os problemas que temos vindo a alinhavar ou a tentar equacionar devem ser formulados e analisados neste quadro. Fora dele, não se vê como tratar a questão das políticas da historiografia. Esta é, sem dúvida, a mais ampla e complexa pois ela percorre de modo latente ou manifesto não só os magnos problemas organizacionais e epistemológicos da história como também as marcas autorais do discurso histórico.

Jacques Le Goff sintetiza a temática em causa nestes termos interrogativos: «Devemos escolher entre uma história-saber objectivo e uma história militante?» $\left({ }^{141}\right)$. Mas até que ponto esta fórmula é apolítica? Serão estas duas famílias historiográficas antagónicas? Excluem-se mutuamente? Será justo distinguí-las no plano da cientificidade? De um lado a história verdadeira, científica, objectiva, neutra, sábia; do outro lado, a história comprometida, serva de ilusões e interesses políticos, falsa, deformada, opaca, subjectiva. Mesmo em termos empíricos, esta diferenciação não pode fundar uma analítica rigorosa dos níveis de verdade na historiografia. Com efeito, adoptamos o princípio segundo o qual o rigor científico ou melhor o regime de verdade possibilitado por cada dispositivo ou "figuration" $\left({ }^{142}\right)$ é praticado independentemente dos temperamentos, convicções ou opções ideológicas dos historiadores.

A história não existe - parafraseando Sartre $\left({ }^{148}\right)$. O que há são histórias e cada uma vive enquanto perdurar o dispo-

(140) Roger Chartier, ob. cit., p. 78. Dos problemas que não podem ser resolvidos à margem da filosofia, o autor aponta "a definição, as condições, as formas de inteligibilidade histórica" (ibidem, Pp. 69); o problema "do objecto ou a querela dos universais» (p. 78 e ss.), entre outros.

p. 79 .

(141) Jacques Le Goff, "História», in ob. cit., p. 241.

(142) Conceito de Norbert Elias; veja-se Roger Chartier, ob. cit.,

(143) Jean-Paul Sartre, Critique de la raison dialectique (précédé de Questions de Méthode), Tome I, Théorie des ensembles pratiques, Paris, Gallimard, 1960, p. 15: «A nos yeux, la Philosophie n'est pas; ....En fait il ya des philosophies». 
sitivo ou conjunto de circunstâncias materiais e epistémicas que suscitaram a sua emergência. As histórias coexistem e sucedem-se e todas elas, como sempre aconteceu desde Heródoto, sabem dar ao seu presente, cuja duração é variável a(s) memória(s) que este reclama. Neste sentido, a história dos historiadores não conhece o anacronismo. Seja ela dita "militante», "sábia» ou outra (para retomar a taxinomia de Jacques Le Goff), em todos os casos, a história está atenta ao modo de ser da sua respectiva actualidade que é já eco do futuro, mas também guarida do passado. Nunca foi, não é, nem poderia ser indiferente às sensibilidades do seu tempo, gnosiológicas, metodológicas e político-culturais. Estas sensibilidades são a fonte do seu rejuvenescimento como sugere Jacques Le Goff ao dizer que "o saber histórico está ele próprio na história, isto é na imprevisibilidade, o que o torna mais real e mais verdadeiro" $\left({ }^{144}\right)$. Com efeito, pode perguntar-se: onde é que a história. em particular a história político-cultural bebe a sua energia inventiva? Donde procedem, hoje, os léxicos administrativo-empresarial e o metafórico-religioso, linguagens que a recente prática historiográfica tem cultivado? $\mathrm{Da}$ configuração actual dos poderes-saberes, em particular da vontade de expansão paradigmática no conjunto do saber, de códigos científicos duros e moles? E quais? É inegável que, hoje, existe um capital epistémico em circulação. inteiramente novo, de acordo com a perspectiva caleidoscópica. Ele tem sido agarrado pela escrita da história, seja a de elevado nível de especialização, seja aquela que pratica cruzamentos e enxertias do tipo demográfico-mental, estético-político, económico-institucional e outros. Enfim, seja ela "saber objectivo» ou "militância» para nos colocarmos no registo de Jacques Le Goff.

Não estamos a esquecer que a grande história ainda existe, ou melhor, o grande historiador (os génios são raros e têm uma paciência de santo). É talvez a grande história que optimiza o sentido latente da "figuration», que transmite às gerações vindouras o rosto da sua época pelo modo como lê o seu presente noutros tempos pretéritos. Ela está para além da militância por um lado e da obsessão de neutralidade por outro lado, entre outras razões porque a grande história apaga e simultaneamente entroniza o seu construtor e isto acontece independentemente deste cultivar a intenção de se reservar na escrita da história. Como escreveu Miguel de

(144) Jacques Le Goff, «art. cit.», p. 245. 
Unamuno: «os grandes historiadores são também autobiógrafos» $\left({ }^{145}\right)$.

Deixando para quem de direito a sistemática classificatória, queremos apenas dizer que a história dos historiadores, globalmente considerada, desde a irrupção do positivismo metódico oitocentista, tem vindo a ser praticada em termos científicos, variáveis consoante o dispositivo em que se inscreve. Logo, a oposição "saber objectivo" - «história militante" dilui-se numa leitura que adopta o princípio da historicidade dos regimes de verdade. Não é anti-científica aquela história que se funda numa estratégia de inteligibilidade consistindo. basicamente, em submeter à prova documental um determinado universo ideativo.

Desde que não tenha a ilusão de neutralidade objectivista, o historiador torna-se sensível a todo um leque de hipóteses e de princípios ideativos; selecciona, faz opções, sempre na esteira da verdade, o que em termos científicos é um procedimento legítimo e fecundo. Os ideatos não afectam o nível de cientificidade que é possível alcançar mesmo que sejam convertidos numa sistemática lógico-ontológica. Nos termos de Georges Gusdorf: "L'enquête ne peut réussir, elle ne va nulle part, si elle n'a pas défini par avance un champ épistémologique, si elle n'a pas orienté la recherche en fonction d'une théorie qui suscite les faits appelés à la vérifier. Le danger de la recherche historique, si elle ne s'appuie pas sur une conceptualisation rigourese, c'est de se perdre dans la poussière des faits comme l'eau disparaît dans les sables du désert» $\left({ }^{146}\right)$. Partir de uma visão sistematizada do tempo, da vida, do poder, da sociedade, da cultura, da técnica e outras não é ideologizar, no sentido pejorativo. a prática historiográfi$\mathrm{ca}$, mas, pelo contrário, operar de acordo com um imperativo científico. A ideia nunca é obstáculo epistemológico mas hipótese que tem de mostrar a sua valia hermenêutica face ao documento. Sempre que a seriedade seja apanágio do historiador, as virtudes das ideias enquanto conceitos rigorosos, são inesgotáveis. E o universo ideativo do historiador que comanda a pesquisa arquivística ou seja, as operações selectivas de materiais. E ele também que orienta o sujeito cognos-

(145) Miguel de Unamuno, "Como se faz uma novela», in A tia Tula, Lisboa, Editorial Verbo. s.d., p. 141.

p. 422 .

(146) Georges Gusdorf, Introduction aux sciences humaines...., 
cente na tarefa de compor, produzindo, não raras vezes, efeitos inesperados sobre as hipóteses construídas no início. Portanto, é no universo ideativo que se alicerçam os resultados científicos e inovadores da prática historiográfica; é do rigor e consistência dos conceitos $\left({ }^{147}\right)$ que dependem as verdades da história.

Também não consideramos anti-científica, a escrita da história que, em nome do ideal de imparcialidade ideológica, procura libertar-se dos apriorismos ideativos e posicionar-se frente à documentação no estado de tábua-rasa. Ố historiador que quer ser neutro e imparcial, cultiva a ilusão objectivista e não se conforma com as condições iniludíveis a que todo o conhecimento está sujeito. "Todo o conhecimento se enraíza numa vida, numa sociedade, numa linguagem que têm uma história; e nessa história mesmo se encontra o elemento que lhe permite comunicar com outras formas de vida, outros tipos de sociedade, outras significações» $\left({ }^{148}\right)$. O ideal de ciência pura e definitiva não reconhece ou não aceita estas condições reais de produção do saber. No fundo, a vontade historiográfica de elidir e neutralizar o tempo, traduz a vontade do historiador de se desistoricizar. Projecto vão, pois o historiador acaba por se confrontar com a polivalência semântica das palavras e dos números e consciente ou inconscientemente por se render perante a sua própria experiência da ambiguidade da linguagem. Então, a recusa de um universo ideativo, de um ponto de vista prévio, necessariamente selectivo e redutor, de apriorismos hermenêuticos volve-se na interpretação espontânea onde se projectam e circulam. sem entraves, os valores filosóficos e ético-políticos do sujeito cognoscente.

Este procedimento historiográfico não é mais nem menos científico do que o precedente, nem fica mais aquém, nem vai mais além relativamente ao regime de verdade do seu tempo. No entanto, este modo de fazer história está mais exposto ao perigo do anacronismo, e como tal, apresenta aptidões mais limitadas para responder ao «interesse prático" e ao «interesse emancipatório» $\left({ }^{149}\right)$ da consciência social. Esta diferença não é jrrelevante porque, de acordo com a "profissão de fé» de Jacques Le Goff, "cabe ao historiador

(147) Veja-se Paul Veyne, ob. cit., pp. 87-96.

(148) Michel Foucault, As palavras e as coisas..., p. 484.

(149) Jürgen Habermas, La Technique et la science comme idéologie, préface et traduction de l'allemand par Jean-René Ladmiral, Paris, Gallimard, 1973, p. 145. 
transformar a história (res gestae) de fardo - como dizia Hegel - numa historia rerum gestarum que faça do conhecimento do passado, um instrumento de libertação» $\left({ }^{150}\right)$. Para responder a estes interesses o historiador deve guiar-se pelo «máximo de consciência possível» $\left({ }^{151}\right)$; deve cultivar o espírito crítico face aos dispositivos do poder na medida em que «o conhecimento não remete nunca para um sujeito que seria livre relativamente a um diagrama de poder, mas também este não é nunca livre relativamente aos saberes que o actualizam» $\left({ }^{152}\right)$.

Não se trata de optar por uma de duas histórias como propunha interrogativamente Jacques Le Goff — ou a «história-saber objectivo" ou a "história militante» — pois espírito científico historiográfico e espírito militante não são antagónicos, tomando-os num sentido dessacralizado, isto é, desde que o primeiro seja autêntico (anti-dogmático, aberto, crítico, vigilante) e o segundo, o mais possível emancipado de sentimentos de tipo religioso. Por esta ordem de ideias, nada há de paradoxal na profissão de fé de Jacques Le Goff que termina com estas palavras elucidativas: «Pertence à própria natureza da ciência histórica, estar estritamente ligada à história vivida, de que faz parte. Mas pode-se e deve-se - e, em primeiro lugar, o historiador - trabalhar, lutar para que a história, nos dois sentidos da palavra, seja outra» $\left.{ }^{(153}\right)$. O que aqui se lê é uma intencionalidade justa que assume a projecção da escrita da história na história vivida; é correlativamente, uma direcção do espírito historiográfico marcada por opções teórico-político-culturais conscientes - posicionamento que não interfere com as exigências do espírito científico, antes faz parte integrante deste. Não se pode esquecer que, qualquer estudo histórico "mesmo o mais honesto, o mais escrupuloso e o mais crítico, conserva sempre o carácter duma aposta explícita ou implícita, a um tempo teórica e prática: teórica quanto ao máximo de adequação possível ao objecto estudado, e prática quanto às possibilidades de transformar a sociedade ou de impedir qualquer transformação)» $\left.{ }^{154}\right)$. Por isso, o historiador tem de optar, não exacta-

(150) Jacques Le Goff, "art. cit.», pp. 244-246.

(151) Lucien Goldmann, A Criação Cultural na Sociedade Moderna. Para uma sociologia da totalidade, trad. de J. Assis Gomes e M. Sabino Morgado, Lisboa, Editorial Presença, 2. ${ }^{2}$ ed., 1976, pp. 7-25.

(152) Gilles Deleuze, Foucault, trad. de José Carlos Rodrigues, Lisboa, Ed. Vega, 1987, p. 105.

(153) Jacques Le Goff, "art. cit.», p. 246.

(154) Lucien Goldmann, Introdução à sociologia, cadernos para o diálogo/nova série, editora nova crítica, s.d., p. 15. 
mente entre ciência e militância, mas entre duas posições políticas na escrita da história: uma espontânea e passiva decorrente da ilusão objectivista (Habermas) e outra reflectida e activa resultante da observância do valor dos ideatos na construção do conhecimento histórico, ideatos que, justamente, não veiculam a claridade absoluta. O historiador não é menos cientista-hermeneuta por assumir, como Jacques Le Goff "trabalhar, lutar para que a história, nos dois sentidos da palavra, seja outra». Pelo contrário, a dinâmica de renovação quer da escrita da história quer da «memória histórica social» depende, significativamente, da assunção do imperativo historiográfico goffiano.

Não é fácil partilhar o entusiasmo de Jacques Le Goff, o mesmo, afinal, que animava Lucien Febvre (e, sabe Deus, se não será ainda o optimismo de Hegel!). O problema é que a história não é propriedade privada do historiador que a construiu. $\mathbf{O}$ destino da obra existe, tanto dentro como fora da comunidade científica. Perante esse destino, tornam-se secundários não só os problemas epistemológicos que o historiador vivenciou na feitura do seu trabalho, como também em certa medida, os princípios que o animaram, constituintes activos da razão de ser do seu "combate», como diria Lucien Febvre. A obra (no sentido imediato do termo) tornada pública, emancipada do seu autor, faz deste um leitor (diferente) entre outros leitores, igualmente diferentes entre si. Pouco importa que a vivência privada dos problemas epistemológicos e terminológicos tenha sido dolorosa, serena, pragmática ou outra, para o historiador; pouco importa que a direcção tomada por ele tenha sido espontânea ou reflectida, que ele tenha perseguido a ilusão objectivista da neutralidade ou que tenha partido de uma sistemática ideativa onto-lógica; pouco importa até o modo de presença da sua "profissão de fé» ou de prescrições de prudência na obra. Tudo isto tem uma importância relativa se considerarmos que, em qualquer caso, a obra publicada tem uma faculdade autónoma de dizer que o autor não pode controlar.

Ninguém sabe o que pode uma obra, parafraseando Espinosa $\left(^{155}\right)$. Se a escrita da história pode e deve ter uma

(155) Bento de Espinosa, Ética demonstrade à maneira dos geómetras, Livro II, trad. de Joaquim Ferreira Gomes, Coimbra, Atlântida, 1962, p. 93: «Ninguém, na verdade, até ao presente determinou o que pode o Corpo». Não só ignoramos o que pode uma obra mas também a palavra e o número pois como escreveu Carl G. Jung «Cada palabra significa algo ligeramente distinto para cada persona, aun entre las que comparten los mismos antecedentes culturales.... Y la diferencia 
capacidade libertadora como quer Jacques Le Goff, isso não depende apenas da intencionalidade do historiógrafo, do método utilizado, do universo conceptual, dos critérios hermenêuticos, do seu cuidado epistemológico, etc., mas também, e acentuadamente, dos interlocutores da obra, dos dispositivos que estes habitam. Com efeito, não há um relacionamento mecânico entre as "memórias matrizes» e as "memórias históricas sociais». Possivelmente, em nenhum tempo e lugar concretos, a consciência social conheceu «uma memória perfeitamente sintonizada com a memória matriz» ${ }^{156}$ ) - a julgar pelo sentido inerente à problematização que Luís Reis Torgal faz no final da sua obra. É que, entre outras circunstâncias, a obra colocada à disposição do público, torna-se um campo semântico aberto que além de devolver ao seu tempo um feixe de verdades onde o presente se reconhece, pode mesmo dar respostas a problemas estranhos ao seu solo originário. E o leitor que "abre» mas também é ele que "fecha» a obra, extraindo dela "verdades». determinando-lhe sentidos e assimilando mensagens "car l'histoire de l'historien est une oeuvre écrite ou enseignée, qui comme toute oeuvre écrite et enseignée, ne s'achève que dans le lecteur, dans l'élève, dans le public» $\left({ }^{157}\right)$. Todavia, a imprevisibilidade do destino da obra histórica não pode ser motivo de alheamento do historiador das suas responsabilidades culturais, dos interesses prático e emancipatório da razão historiográfica. Pelo contrário deve fundar a necessidade de se imprimir na escrita da história o máximo de rigor argumentativo e documental, ou monumental como se prefere, hoje.

Recorde-se que a história «desde o fundo da idade grega, exerceu na cultura ocidental um certo número de funções capitais: memória. mito, transmissão da Palavra e do Exemplo, veículo da tradicão, consciência, crítica do presente decifracão do destino da humanidade, antecipação ao futuro ou promessa de um retorno" ( $\left.{ }^{158}\right)$. Actualmente, se a sua aptidão para dar resposta aos interesses prático e emancipatório da consciência social está dependente das sensibilidades polí-

de significado es naturalmente mayor cuando la gente difiere mucho en experiencias sociales, políticas, religiosas o psicológicas.... Hasta el concepto filosófico o matemático más cuidadosamente definido, del que estamos seguros que no contiene más de lo que hemos puesto en él, es, no obstante, más de lo que suponemos», El Hombre y sus simbolos, trad. do inglês por Luis Escobar Bareño, Madrid, Aguilar, 2.a ed., 1979, p. 40.

(156) Luís Reis Torgal, ob. cit., p. 249.

(157) Paul Ricoeur, Histoire et Vérité...., p. 35.

(158) Michel Foucault, As palavras e as coisas...., p. 477. 
tico-culturais em jogo, não o está menos dos valores que a obra transmite e portanto da dimensão normativa-político-cultural própria do seu ordenamento científico. Nesta perspectiva, a dessubjectivação do conhecimento histórico não é um ideal epistémico porque as marcas pessoais são sintomas de apropriação cognitiva no duplo sentido teórico e prático exposto por Lucien Goldmann, e não sinal de imperfeição historiográfica. Indo ao encontro do nosso ponto de partida, podemos, agora, reafirmar que o modelo de inteligibilidade compreensiva do acontecer histórico convém a uma história que, não abdicando do máximo de cientificidade possivel, se quer viva, comprometida e actual. Em suma: importa não esquecer que é também no "carácter autobiográfico e auto-referenciável» ${ }^{\left({ }^{159}\right)}$ do conhecimento histórico que se enraíza a consistência científica inovadora e o seu alcance político-cultural, de acordo com as exigências humanísticas do paradigma pós-moderno.

"Ciência com consciência" $\left({ }^{160}\right)$, diz Edgar Morin. No caso da História, as suas responsabilidades científico-culturais passam pelo abandono da ilusão objectivista de neutralidade subjectiva (Habermas). Neste âmbito, assume particular relevo o exercício do espírito crítico, no sentido de se operar com o máximo de consciência possível (Goldmann) relativamente quer à espessura da linguagem e aos valores que ela veicula, quer aos interesses prático e emancipatório (Habermas) das sociedades - na certeza, porém, de que a dimensão valorativa da linguagem não pode ser apagada, como ensina, por exemplo, a filosofia da linguagem sucessora do positivismo lógico e retórico. Vale a pena acrescentar que a linguagem, enquanto medium de comunicação «inevitably proclaims values by its nature as a code and by virtue of its users' choises" ( $\left.{ }^{161}\right)$. Como defendem Richard M. Weaver, Kenneth Burke. Paul Newell Campbell "values and their linguistic expression lay at the heart not only of science but of all forms of human communication.... not only is it pragmatically impossible to denude language of values. but to attempt to do so is to do violence to the social structure» $\left.{ }^{162}\right)$. $\mathrm{O}$ historiador tem de contar com

(159) Boaventura de Sousa Santos, ob. cit., p. 53.

(160) Edgar Morin, Ciência com consciência, Publicações Europa-América, s.d.

(161) Douglas Ehninger and Gerard A. Hauser, "Communication of Values», in Carroll C. Arnold, John Waite Bowers, Handbook of Rhetorical and Communication Theory, Boston, London, Sydney, Toronto, Allyn and Bacon, Inc., 1984, p. 745.

(182) Idem, ibidem, pp. 720-725. 
esta realidade. Se não pode ser o gestor absoluto desses valores, pelo menos, pode investir neste campo, reforçando o seu espírito de precisão relativamente aos sentidos dos jogos normativos, axiológicos e políticos da linguagem historiográfica, ou seja: ele não deve desinteressar-se ou ficar indiferente às mudanças valorativas que se operam na (sua) escrita da história, sejam elas deliberadas ou não, o que é sempre relativo, pelo que acabámos de ver. $\mathrm{O}$ mesmo se diga quanto às mudanças valorativas que a obra vive ao circular nas memórias heterogéneas dum público diversificado. Não podemos seguir este filão até ao fim em virtude da riqueza de denominadores que ele envolve. Então, diremos apenas que, por ser impossível desnudar a linguagem dos valores, e sobremaneira a prosa historiográfica, é da máxima importância (em termos de "exactidão, consistência, alcance, simplicidade e fecundidade» ( $\left.{ }^{163}\right)$ ) que o historiador faça e torne manifestas as suas opções sem as dogmatizar, segundo a lição de Lucien Goldmann.

A actualização científico-cultural da história passa ainda pelo questionamento da "metafísica simplista do pedreiro" $\left({ }^{164}\right)$ embora, tanto no caso português (apesar da "evidente desmarxização" ( ${ }^{165}$ ) depois de 1978) como noutros casos, continue a ser um abrigo seguro. A sua consistência não se abala facilmente porque essa "metafísica» revolucionária construiu cidades sólidas e disciplinadas que nada têm de labiríntico ou indeterminado. Elas estão a milhas de distância das cidades impacientes e caóticas de Paul Veyne e estas talvez não possam soterrar aquelas cidades exemplares, "perfeitamente governadas", segundo o modelo da peste (Foucault) ou o modelo geológico ( $\mathrm{P}$. Veyne). E, no entanto, o comentário de Lucien Febvre à "metafísica simplista do pedreiro" é de uma acuidade tão manifesta que não resistimos a dar-lhe aqui a atenção que merece: "...é muito curioso verificar que hoje, num mundo saturado de electricidade, quando a electricidade nos ofereceria tantas metáforas apropriadas às nossas necessidades mentais, nos obstinamos ainda em discutir com toda a seriedade metáforas vindas do fundo dos séculos, pesadas, deselegantes, inadaptadas, nos obstinamos em pensar as coisas da história por camadas, por andares, por pedras por alicerces e por superestruturas» $\left.{ }^{186}\right)$. Com quaren-

(163) Thomas S. Kuhn, A tensão essencial, Lisboa, Edições 70, 1989 , p. 385 e ss.

(164) Lucien Febvre, ob. cit., p. 34.

(185) Luís Reis Torgal, ob. cit., p. 165 e ss.

(166) Lucien Febvre, ob. cit., pp. 34-35. 
ta e oito anos de idade, este pedaço de escrita simboliza, ainda hoje, a consciência crítica da historiografia que desde a década de cinquenta tem vivido tempos complexos de desenvolvimento, salutarmente diversificado. Mas, se este período de esgotamento dos modelos da modernidade ou talvez de transição paradigmática culminou na actual "crise profunda» de que fala J. Le Goff, ou no «inferno da confusão» de P. Veyne, ou então na "encruzilhada epistemológica» de Luís Reis Torgal, isto não significa que a história possa ou deva prescindir do materialismo histórico e particularmente dos efeitos estabilizadores que este produz no saber historiográfico. Claro que nada de seguro se pode adiantar relativamente à historiografia do séc. XXI.

Em todo o caso, as "metáforas vindas do fundo dos séculos» de que nos falava Lucien Febvre são, a nosso ver, entidades demasiado poderosas para se deixarem derrubar por imagens (ainda) tão jovens como as procedentes do mundo da electricidade. De resto, a própria consciência crítica da historiografia exposta naquelas palavras argutas e sugestivas permanece envolta numa obsessão de tipo fisicalista: correntes eléctricas, curto-circuitos, descargas, radiações electromagnéticas, motores... Por isso, não podemos deixar de observar que, em qualquer cidade historiográfica, seja ela mais disciplinada ou mais caótica, barulhenta ou introvertida, o "electricista" não substitui o "pedreiro" - e poder-se-ia acrescentar - nem o "arquitecto", nem o "jardinheiro", etc., etc.... Dizendo de outro modo: não faz sentido pôr de lado o método das «fiadas» ou dos "andares» para "fazer passar as correntes pelo fio, as suas interferências, os seus curto-circuitos" ( $\left.{ }^{167}\right)$; não faz sentido abandonar a epistemologia marxista para abrir caminhos de renovamento da historiografia e impulsionar uma reflexão historiosófica atenta e aberta aos movimentos e resultados que, entretanto, se vão estabelecendo noutras áreas do conhecimento, com realce para os saberes científicos de tipo duro. Realce, porque, independentemente dos limites da consciência crítica da historiografia, impõe-se concluir que as físicas continuam a maravilhar a história.

A nosso ver, toda a intenção de criar história que à partida nadifique os bens historiográficos e historiosóficos que o passado nos legou, afigura-se-nos algo insensata. Dir-se-ia

(1er) Idem, ibidem. 
mesmo que uma tal postura epistemológica é sobremaneira absurda como se se tratasse do apagamento físico ou simbólico das memórias artística, literária, musical e outras das cidades da velha Europa.

Queremos então sublinhar que, além das razões de ordem epistemológica que conferem valor ao materialismo histórico, há ainda a auto-necessidade da escrita da história de manter viva e actual a sua própria historicidade. Ora, este imperativo que sintetiza a singular identidade do saber histórico, realiza-se pela incorporação no seu ser actual e optimização consequente das lições do passado. A história não pode simplesmente arquivar a lição marxista com toda a sua complexidade filosófica-política-científica (irredutível a receituários ou catecismos dogmáticos), como a biologia não pode renunciar a Darwin. Por tudo isto julgamos que a estratégia política da historiografia actual não pode inutilizar o capital teórico que instituiu as suas bases científicas, o que não significa que deva fechar-se nele passiva e acriticamente.

Mas, os problemas que a história actual tem de enfrentar não residem primordialmente nos alicerces do seu tecido científico-literário; antes, localizam-se nos espaços fronteiriços onde circulam figuras de outras disciplinas que estabelecem relações equívocas com a história, muitas vezes bloqueadoras e neutralizantes das suas potencialidades compreensivas e explicativas do acontecer. Neste âmbito, o que fundamentalmente está em jogo é o sentido do tráfego interdisciplinar. A história teria todas as vantagens em invertê-lo e diversificá-lo criteriosamente. Se, enquanto receptor mais ou menos conformista, o oceano historiográfico se encontra saturado de produtos epistemológicos que não se inter-harmonizam, por integrarem na sua composição elementos ideo-políticos incompatíveis entre si; se, aqueles produtos apenas concorrem para a "encruzilhada epistemológica» da história, então isto significa que a história tem de rever a sua posição face às disciplinas humanas. Em lugar de acolhedora de enunciados moles, deve tornar-se emissora de problemas, tomando a iniciativa de abrir portos transdisciplinares, mas mantendo com firmeza a sua identidade historiocêntrica e a sua capacidade decisória relativamente às respostas dadas àquelas questões pelas diversas disciplinas interpeladas. E esta problematicidade da actual economia epistemológica da história que urge repensar nas suas múltiplas faces. A este propósito, as quatro ou quase cinco décadas que passaram sobre o alerta irónico e oportuno de Marc Bloch e Lucien Febvre, atinente à definição de história, 
não diminuiram a plenitude e a intensidade da sua mensagem. Evoquemos, pois, para terminar, a sua escrita viva:

«Definir, definir, mas não será isto maltratar? 'Atenção, meu amigo, você vai sair da história.... Releia a munha detiniçao, ela é tẫo clara!.... Se é historiador, não pode por aqui os pés: é o domínio do sociólogo. Nem ali, é o dominio do psicólogo. A direita? Não pense nısso, é o do geografo.... E à esquerda, é o do etnógrafo....' Pesadelo. Disparate. Mutilaçao. Abaixo os compartımentos e as etıquetas! E na tronteira, sobre a tronteıra, um pé deste lado, um pé daquele, que o historiador deve trabalhar livremente. Utilmente..... (168).

Quer dizer: a história pode continuar a ser o oceano pacífico que as cièncias humanas atravessam à superfície e marcam de acordo com a sua estratégia teórica-prática; pode ser um mar aberto onde a sociologia, a psicologia, a etnografia e outras encontram a sua "pátria» e nela instalam os seus cálculos, leis, fantasmas e testam os seus modelos - na condição, porém, de não limitarem os movimentos da história e de não estranharem que a história as interrogue, utilize ou abandone pois «.... historiador deve trabalhar livremente. Utilmente....». Por isso a institucionalização da liberdade transdisciplinar como parte integrante da estratégia historiográfica actual requer o estabelecimento de uma discursividade metodológica aberta, flexível mas simultaneamente firme e segura, capaz de dinamizar os equívocos, incertezas e tensões na escrita da história. Esse movimenta a transmitir aos problemas é fundamental porque modifica-os nalguns casos, extingue-os noutros ou ainda pode inutilizá-los. Assim, de todas as razões apontadas para afirmar a necessidade de discursos do método na história, esta não é, certamente, de somenos importância. Pelo contrário, os exemplos a que recorremos, seja a historiografia positivista face à ofensiva do sociologismo seja o ideal historiográfico de J. Le Goff e a sua queda no antropologismo, autorizam-nos a dizer que o problema (político) da relação da história com outros campos do conhecimento é aquele que denota, em flagrante, a carência de discursos do método na história. 